\title{
HISTORICAL EXAMINATION OF DELAYED PLUMAGE MATURATION IN THE SHOREBIRDS (AVES: CHARADRIIFORMES)
}

\author{
PHILIP C. CHU \\ Museum of Zoology and Department of Biology, University of Michigan, \\ Ann Arbor, Michigan 48109
}

\begin{abstract}
Delayed plumage maturation refers to the presence of nonadultlike immature plumages (juvenal plumage excluded). It is usually considered the result of selection for distinctive firstwinter or first-summer appearance. In the present study, evolution of delayed plumage maturation is examined in the shorebirds: the sandpipers, plovers, gulls, and their allies. Nine plumagematuration characters were identified, and their states were superimposed onto topologies generated during two recent investigations of shorebird relationships (Sibley and Ahlquist; revised Strauch). The characters were then optimized so as to assign character states to interior nodes of the trees in the most parsimonious way.

Reconstructions of character evolution on six of the shortest revised Strauch trees were ambiguous with respect to delayed plumage maturation in the hypothetical ancestral shorebird. If plumage maturation was not delayed in the shorebird ancestor, optimization indicated that delay appeared when nonadultlike juvenal feathers were acquired. In contrast, on the single Sibley and Ahlquist tree, absence of delayed plumage maturation in the shorebird ancestor was indicated unambiguously, with three evolutionary novelties (nonadultlike juvenal feathers, seasonal plumage change, and a reduced first-spring molt) implicated in its acquisition.

Optimization indicated that delayed plumage maturation in shorebirds can be explained plausibly without invoking selection for distinctive first-winter or first-summer appearance. Two of the novel conditions generating delayed plumage maturation (modified juvenal feathers and seasonal plumage change) did so only because they were acquired in a taxon possessing restricted first-year molts, which are primitive. Given these observations, it seems simplest to explain the delay in plumage maturation as an incidental consequence of the phylogenetic inertia of shorebird molts. The third novelty that generates delayed plumage maturation, a reduced first-spring molt, may have been acquired to reduce molt-associated energetic demands in young birds.
\end{abstract}

Key words. - Character evolution, delayed maturation, molt, plumage, shorebirds.

Received June 10, 1991. Accepted November 10, 1992.

In their first year, birds typically pass through four plumages, a downy one followed by three that include contour feathers. The latter are, in order of appearance, juvenal, first-winter, and first-summer plumages. In subsequent years, each individual has only two plumages per year, a winter one and a summer one. Both of these include contour feathers as well.

The color and pattern of contour feathers may be invariant across all age and sex classes in a species. In many species, however, feather appearance varies with time of year, sex, age, or some combination of the three.

When a bird's appearance varies with age, it is said to exhibit delayed plumage maturation; that is, it shows delayed, rather than immediate, acquisition of a "mature" or adultlike plumage. The exception to this rule is juvenal plumage. Juvenal feathers differ from their adult counterparts in fine structure (e.g., Gohringer 1951) and sometimes in shape as well. In addition, many of them are worn only briefly. As a consequence, juvenal plumage is perceived as a specialization for fledglings; even when it looks different from any adult plumage (e.g., fig. 1), it is not considered part of the delayed-plumage-maturation phenomenon.

The immature plumages associated with delayed plumage maturation may be evident for one year or for many. Most shorebirds and passerine birds with immature plumages take about $1 \mathrm{yr}$ to acquire adult plumage; large gulls take 4 $\mathrm{yr}$, and large tubenoses like the wandering albatross (Diomedea exulans) take 20 to $30 \mathrm{yr}$ (Cramp and Simmons 1977). For the sake of simplicity, this paper will use delayed plumage maturation to refer only to postjuvenal, nonadultlike plumages worn during the first year, that is, nonadultlike first-winter and first-summer plumages.

Students of delayed plumage maturation ask the question, "Why not look like an adult?" The hypotheses proposed to answer this question suggest that the delayed assumption of adult plumage is 
the result of selection for distinctive first-winter or first-summer appearance, with distinctive appearance being an adaptation for the special conditions that first-year birds are thought to face. The hypotheses fall into three broad classes: cryptic hypotheses, mimetic hypotheses, and the winter-adaptation hypothesis.

The cryptic and mimetic hypotheses propose that delayed plumage maturation is an adaptation related to breeding. Both assume that firstyear birds lack experience and are thus handicapped when trying to breed. Both also recognize that birds less than 1-yr old sometimes do breed successfully.

The cryptic hypotheses propose that the inexperience of first-year birds makes breeding a costly, low-return endeavor for them. They may breed if a suitably low-cost opportunity is available; if not, however, they forgo breeding and maximize early survival, thereby possibly increasing their lifetime reproductive success (Lack 1954, 1968; Wittenberger 1979; Studd and Robertson 1985).

The maximization of early survival has been linked to delayed plumage maturation in two ways. One is direct: Procter-Gray and Holmes (1981) suggested that early survival is maximized by wearing a cryptic plumage that helps young birds escape detection by predators and potentially aggressive adults. The second is indirect and hinges on the enhanced survivorship of young birds that do not expend energy in a breeding attempt. Selander (1965), Ficken and Ficken (1967), and Wiley (1974) argued that selection against early breeders results in delayed gonadal development, which in turn leads to reduced plasma sex-hormone levels in young birds and a delay in the assumption of adult plumage.

The mimetic hypotheses suggest that first-year birds wear a plumage mimicking an age or sex class that older birds treat less aggressively (Rohwer et al. 1980; Foster 1987). By tricking older birds into reduced aggression, the deceitful plumage signals are hypothesized to compensate somewhat for the inexperience of young birds, thereby improving their chances for breeding successfully.

Unlike the cryptic and mimetic hypotheses, the winter-adaptation hypothesis (Rohwer et al. 1983; Rohwer and Butcher 1988) proposes that nonadultlike immature plumages are important during the winter, for reasons that are not directly related to breeding, for example, avoiding predation or signaling status (Rohwer and Butcher
1988). Their retention into the following breeding season could then be explained in terms of molt constraints; Rohwer et al. (1983) and Rohwer and Butcher speculated that an extensive molt from winter to summer plumage may have been difficult to evolve, or that it may require a prohibitively large energy expenditure.

Previous comparative investigations of delayed plumage maturation used the hypothesized functions of immature plumages to generate predictions, and then asked whether the predictions are better satisfied in species with immature plumages than in species without them (e.g., Rohwer et al. 1980; Studd and Robertson 1985; Lyon and Montgomerie 1986). This approach is useful; however, the investigations themselves were designed without considering phylogeny.

Phylogenies are a widely used tool for examining evolutionary problems (e.g., Sillén-Tullberg 1988; Donoghue 1989; Lauder 1989; Brooks and McLennan 1991; McKitrick 1992). Phylogenetic hypotheses are important because they estimate patterns of ancestry and descent, thereby providing a historical framework that can be used to structure questions about character evolution (e.g., Ridley 1983; Felsenstein 1985; Coddington 1988; O'Hara 1988; Pagel and Harvey 1988; Burghardt and Gittleman 1990). For example, phylogenetic trees can be used to assess the polarity of a particular trait; polarity, in turn, determines the direction from which the trait is examined (Ridley 1983; Coddington 1988). If delayed plumage maturation is derived within a lineage, the question, "Why was plumage maturation delayed?" is useful, but if it is primitive, the more appropriate question is, "Why was plumage maturation accelerated?" Previous contributors to the delayed-plumage-maturation literature assumed that delay is the derived condition, but did not test the assumption.

In addition, a hypothesis of historical relationships permits the identification of control groups for testing ideas about function. Earlier studies of delayed plumage maturation selected species for analysis on the basis of their membership in a subset of a particular avifauna, for example, North American passerine birds. However, the appropriate taxa to select are those belonging to lineages that arose immediately before and after the point in history at which delayed plumage maturation arose (Coddington 1988). Thus, if a delay in plumage maturation is thought to have arisen in the most recent common ancestor of a particular ingroup, comparison of in- 
group members versus several proximate outgroups would be appropriate.

Finally, a resolved phylogeny allows inferences about homology of function to be made (Coddington 1988). If a derived feature is shared because of common ancestry, then it is logical to assume homology of both the feature and its function. Conversely, if a derived feature has two or more independent origins, its functions cannot be homologous. Previous investigations sought a common function for delayed plumage maturation, and understandably so: the search for generalities is an important feature of comparative investigations. However, if multiple origins of delayed plumage maturation are indicated, it may be more profitable to examine separately each group in which the phenomenon arose. In this way, nonhomologous functions are treated as such and can be compared, illuminating the similarities and differences between them.

Here I examine the evolution of delayed plumage maturation in the shorebirds: the sandpipers, plovers, gulls, and their allies (Aves: Charadriiformes). My objective is to assess the plausibility of hypotheses that explain distinctive firstyear plumages as an adaptation for first-year living conditions. Unlike previous investigators, I use explicit phylogenetic hypotheses as my frames of reference. In addition, unlike earlier studies (which treated plumage maturation as a single character with two states, "delay present" and "delay absent"), I use a series of feather and molt characters to describe plumage ontogenesis. A multicharacter description of plumage ontogenesis more accurately depicts the several sources of variation affecting a bird's appearance at any one time.

\section{Plumage-Maturation Terminology}

Although plumage and molt terminology was standardized by Humphrey and Parkes (1959), I do not employ their nomenclature. I use a naming system that emphasizes the time of year at which molts occur, or during which particular feather generations are worn.

Molt is the replacement of feathers. By periodically replacing feathers, molt maintains the integrity of the plumage so that the plumage continues to be useful for flight and insulation (Payne 1972). Molt also creates the potential for regular changes in appearance.

Most birds living in temperate regions have two molts per year, one in the fall and one in the spring. The molts may vary with age: most com- monly, birds less than a year old exchange fewer feathers than older birds do. In the shorebirds, for example, the molt during a young bird's first fall is usually partial, whereas subsequent fall molts are complete. Similarly, the first spring molt is often less extensive than are molts in later springs. Because first-year molts are frequently more limited than molts in subsequent years, I refer to molts as either first fall, first spring, adult fall, or adult spring.

Every molt brings in a new generation of feathers. The molt that replaces a chick's natal down brings in juvenal feathers, fall molts bring in nonbreeding feathers, and spring molts bring in breeding feathers. Thus, the first fall molt gives rise to first nonbreeding feathers, the adult fall molt to adult nonbreeding feathers, and the adult spring molt to adult breeding feathers (fig. 1).

However, many molts exchange only some of a bird's full complement of feathers. That is, the coat of feathers worn after a particular molt is finished (called a plumage) may include only some feathers that are newly grown. The rest are older, having been grown during previous molts. Thus, a plumage may be a mosaic of both new feathers and old ones.

Regardless of its composition, the coat of feathers worn after completion of a fall molt is called a winter plumage. The coat of feathers worn after completion of a spring molt is called a summer plumage. Thus, for example, the firstfall molt leads to first-winter plumage; the adult fall molt, to adult winter plumage; and the adult spring molt, to adult summer plumage.

Figure 1 illustrates the mosaic quality of many plumages by depicting one region of plumage in the red knot Calidris canutus, a shorebird with some molts that are partial and others that are complete. After each complete molt, a wholly new coat of feathers is worn: all feathers are scalloped after the postnatal molt, and all are plain after the adult fall molt. Conversely, after each partial molt, the plumage worn is a mixture of new and old feathers. First winter plumage has both plain and scalloped feathers; first summer plumage, both dark-centered and plain feathers; and adult summer plumage, both patterned and plain feathers.

\section{Characters Conferring Delayed Plumage Maturation}

Delayed plumage maturation is the condition in which first-year birds look different from older birds. Resemblance to an adult plumage is, how- 


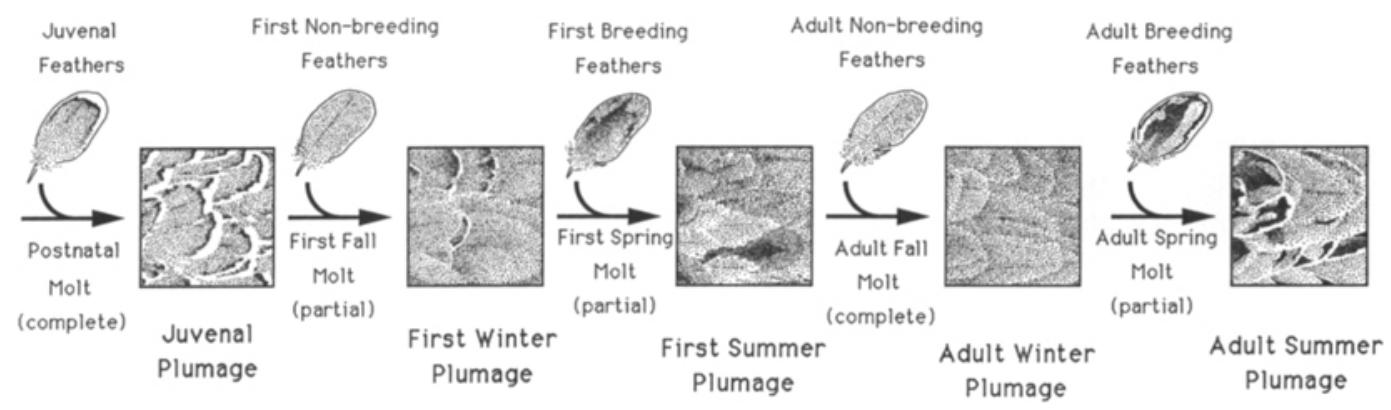

TIME

FIG. 1. Molts, feather types, and plumages in a representative shorebird, the red knot Calidris canutus. The feathers shown are from the posterior scapulars and adjacent back in the following skin specimens: UMMZ $64878,113447,123852,123877$ and 123901 . Notice especially that a plumage may include both newly grown feathers and older ones. For example, first winter plumage includes new first nonbreeding and old juvenal feathers (plain and scalloped, respectively), and first summer plumage includes new first breeding and old first nonbreeding feathers (dark-centered and plain, respectively).

ever, a composite quality. It is determined by the interplay of several characters. States for these characters are listed in Appendix 1.

1. Extensiveness of the First Fall Molt. - The first fall molt determines the composition of first winter plumage. If the molt is limited, first winter plumage includes only a few new feathers and many old ones. If it is more extensive, the proportion of new feathers is higher. Contrast figure 2B2 with figure $2 \mathrm{C} 2$. Both show new feathers as white squares and old feathers as hatched squares. In figure $2 \mathrm{~B} 2$, the first fall molt is limited, so the number of white squares, that is, the number of new feathers, is limited as well. In figure $2 \mathrm{C} 2$, the first fall molt is more extensive, and there are more white squares.

2. Appearance of the First Nonbreeding Feathers. - If a bird has a first fall molt, the plumage it wears during its first winter will include at least some newly grown feathers (the first nonbreeding feathers). The appearance of those feathers will affect the appearance of first-winter birds. Compare figures $2 \mathrm{C}$ and $2 \mathrm{D}$. In the former, first nonbreeding feathers and adult nonbreeding feathers are alike, whereas in the latter they are not. The consequence is that, in the former, first and adult winter plumages are comparatively similar, but in the latter they are less so.

3, 4, and 5. Appearance of Retained Juvenal Feathers. -As long as the first fall molt is partial, some juvenal feathers are retained and contribute to the appearance of first winter plumage.
Two possible conditions of juvenal feathers are shown in figure 2 . In figure $2 \mathrm{~B}$, juvenal feathers are hatched, unlike their adult nonbreeding counterparts; retention of some hatched feathers makes first-winter birds look different from winter adults. Juvenal feathers are also retained in figure $2 \mathrm{~A}$, but they are white instead of hatched; because they look like their adult nonbreeding counterparts, first winter and adult winter birds look alike. To better indicate the appearance of juvenal feathers, I described them from three large regions, each of which was listed as a separate character: the foreneck, breast, and flanks (character 3 ), the belly and under-tail coverts (character 4), and the upperparts (character 5).

6 and 7. Extensiveness of the Spring Molt. Character 6 refers to the first spring molt; character 7 , to subsequent ones. During the spring molt, at least some feathers worn during the winter are exchanged for new breeding feathers. A more extensive spring molt means that more breeding feathers are acquired.

8. Seasonal Changes in Plumage Appearance. - Seasonal plumage variation creates predictable changes in plumage color or pattern. When coupled with age-related variation in the spring molt, it may help to generate age-related plumage differences. For example, compare figures $3 \mathrm{~B}$ and $3 \mathrm{C}$; in both there is seasonal change, with black breeding feathers replacing white nonbreeding ones. In figure 3C, the first spring molt is just as extensive as adult spring molts are, so 
1

2

3

Juvenal

Plumage

A

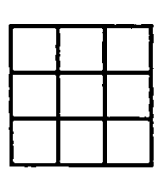

First Winter

Plumage

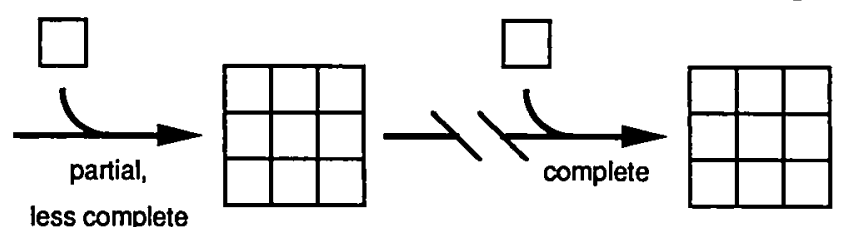

\section{Adult Winter \\ Plumage}

$\mathbf{B}$
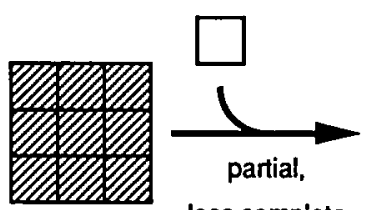

less complete
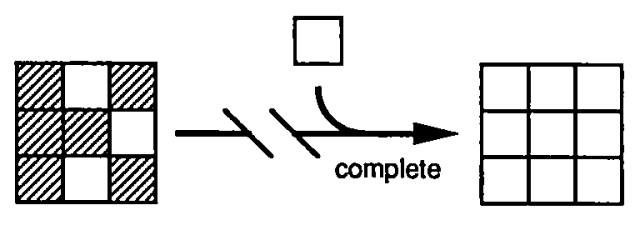

C
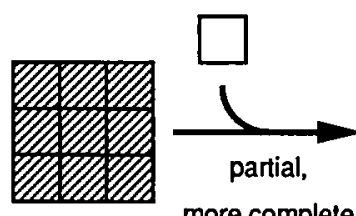

more complete
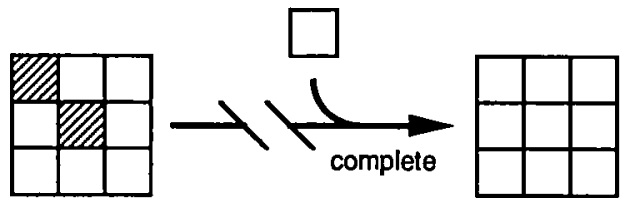

D

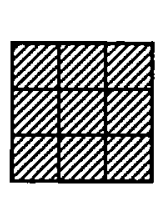

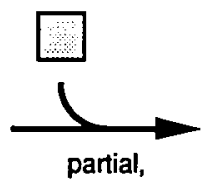

more complete

First Fall

Molt
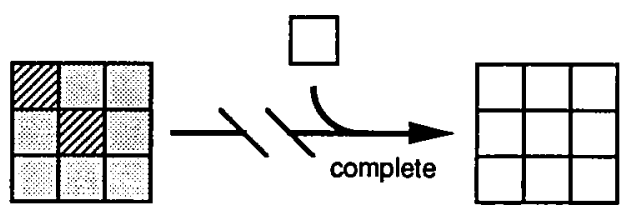

\section{Adult Fall}

Molt

FIG. 2. The interplay of juvenal feathers, the first fall molt, and first nonbreeding feathers in creating first winter plumage. Each row has three panels, and each panel has nine squares; all panels represent the same region of plumage, with each square being a feather in that region. First winter plumages are shown $(A, B)$ after a restricted first fall molt; (C) after a more extensive first fall molt; and (D) after an extensive molt that brings in first nonbreeding feathers that differ from their adult nonbreeding counterparts. Note that, in B, C, and D, first winter plumage is different from adult winter plumage (shown for reference in column 3 ). In $B$ and $C$, they differ because first winter plumage has some juvenal feathers that were not molted out; in $D$, not only were juvenal feathers retained but distinctive first nonbreeding feathers were grown in.

that first-year birds molt in as many black feathers as older birds do. In figure $3 \mathrm{~B}$, however, the first spring molt is less extensive, and young birds bring in fewer black feathers and thus look less black than adults.

\section{Appearance of the First Breeding Feathers. -} Any bird with a first spring molt will carry at least a few first breeding feathers in its first summer plumage. The appearance of these feathers can help to determine whether first-year birds 


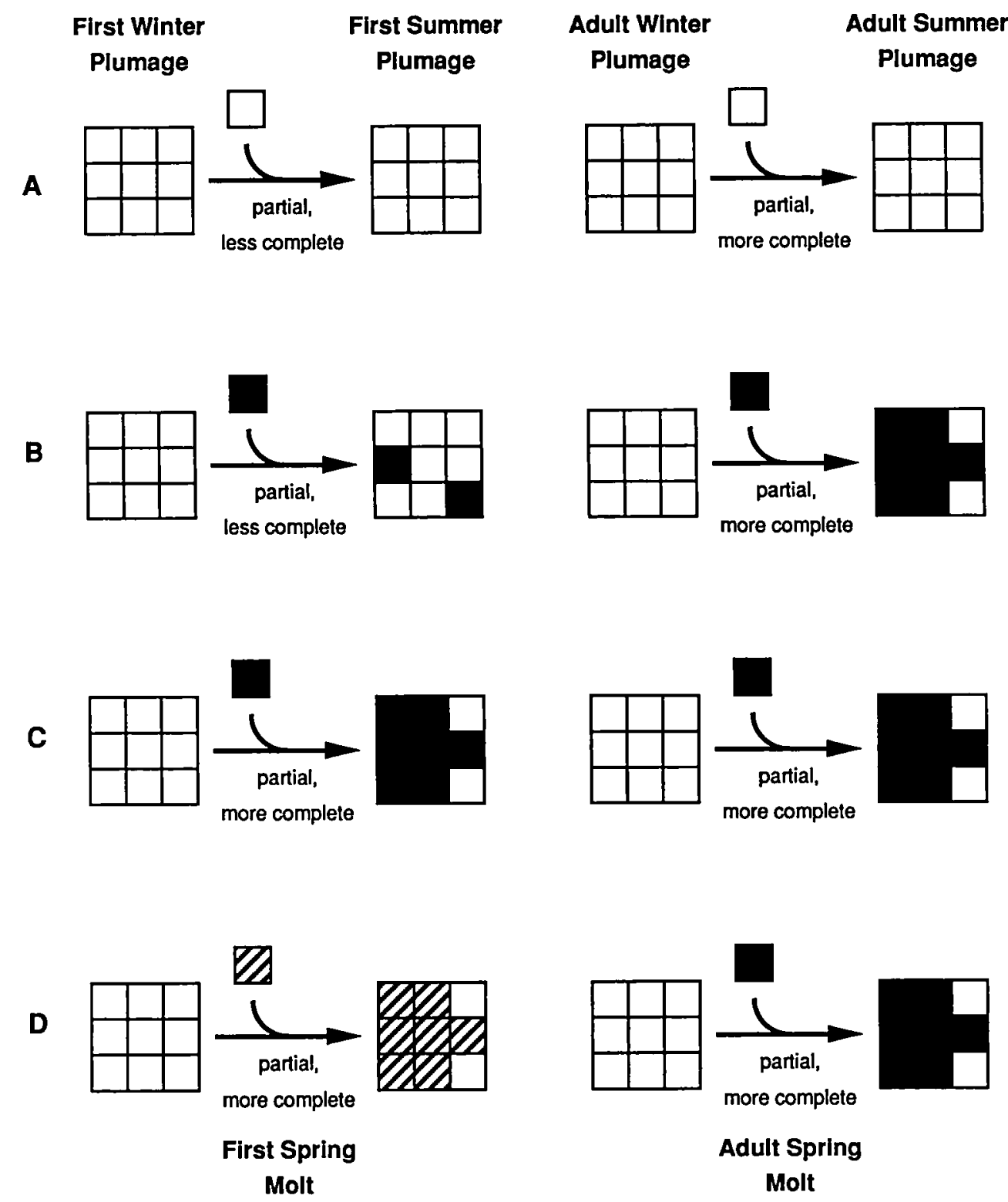

FIG. 3. The interplay of breeding feathers, the spring molt, and seasonal plumage change in creating summer appearance. Each nine-square panel represents the same region of plumage, and each square in the panel is a single feather located in that region. First and adult summer plumages are contrasted under four sets of conditions. A, The first spring molt is less extensive than the adult spring molt, but there is no seasonal change (i.e., breeding and nonbreeding feathers are alike). B, The first spring molt is less extensive than the adult spring molt, and plumage changes seasonally (i.e., breeding and nonbreeding feathers are different). C, First and adult spring molts are coextensive, and plumage changes seasonally. D, First and adult spring molts are coextensive, and plumage changes seasonally, but first breeding feathers look different from their adult breeding counterparts. Note that, for purposes of simplification, first winter and adult winter plumages are shown as being alike. Note also that first and adult summer plumages differ in B and D. In B, first year birds grow fewer of the black breeding feathers than do older birds; in D, both age classes grow the same number of new feathers, but first breeding feathers look different from adult breeding feathers (striped rather than black). 
look like adults. In figure $3 \mathrm{C}$ both first and adult breeding feathers are alike, and there are no agerelated differences in summer plumage. However, in figure 3D, first breeding feathers are striped rather than black, conferring a distinctive appearance on first-summer birds.

Molt-character states merit additional explanation. States for the molt characters are defined by the groups of feathers that they include. For example, examine character 1 , which describes the first fall molt. State 2 describes a first fall molt that replaces the head, neck, and body feathers, some upper secondary coverts, and sometimes the central tail feathers; state 5 describes a similar molt, but one that includes some primaries and secondaries as well. All taxa with state 5 , but none with state 2 , grow new primaries and secondaries during the first fall.

Molt-character states are also partially defined on the basis of individual variation. Referring again to character 1 , state 3 describes a first fall molt that is similar to the state- 2 molt at its minimum extent, and to the state- 5 molt at its maximum extent: some individuals grow no new primaries and secondaries, others grow a few, and still others grow a complete new set. Thus, taxa with state 3 show more individual variation than do taxa with states 2 or 5 .

The use of individual variability to help define molt-character states made questionable the accuracy of certain state assignments. Since states for the molt characters are defined in part by a molt's variability, considerable experience with molting birds is necessary to insure that the variability will not be underestimated. Such experience is lacking for some less well-known taxa. As a result, a taxon might be assigned one of the character states indicating less variability when, in fact, it has a molt that is more variable.

The present study assumes that each molt and feather character is independent. Since molts provide a vehicle for regular changes in appearance, one might suspect that there is a relationship between molts and the respective plumages they produce. However, I observed no covariation between any molt and feather characters; nor did I find covariation between any two molt characters, or any two feather characters.

\section{Materials AND Methods}

Character-state information for the nine plumage-maturation characters was obtained from Jehl (1975), Crome and Rushton (1975), Burger (1979),
Cramp and Simmons (1983), Harrison (1983), Cramp (1985), Hayman et al. (1986), and Urban et al. (1986). The single exception was character 5 in Actophilornis africana, which was determined from skin specimens (UMMZ 152849 and 152850) after it became apparent during the course of another study that those specimens did not match published plumage descriptions. States from each character were then superimposed onto two estimates of shorebird relationships, one generated from molecular data (Sibley and Ahlquist 1990; fig. 4A) and the other based on morphology (from data presented in Strauch 1978; fig. 4B). These are the only studies of shorebird relationships that are both recent and comprehensive.

The Sibley and Ahlquist estimate (fig. 4A) was generated using DNA-DNA hybridization (Schildkraut et al. 1961; Britten and Kohne 1966; Shields and Straus 1975; Sibley and Ahlquist 1981). It includes 69 shorebirds. Strictly speaking, it is a phenogram, not a cladistic phylogeny; Sibley and Ahlquist present it as a phylogenetic hypothesis by assuming that the rate of molecular evolution in different avian lineages, when averaged over the entire nuclear genome, is approximately constant (Sibley and Ahlquist 1984, 1990). However, Sibley and Ahlquist's results do not always support the constant-rate assumption (Houde 1987; Sibley and Ahlquist 1990), and both their data analysis and interpretation have been criticized (e.g., Brownell 1983; Cracraft 1987; Sheldon 1987; Sarich et al. 1989; Springer and Krajewski 1989; Lanyon 1992).

Strauch (1978) used 70 characters, most of them osteological, to estimate relationships among 227 shorebirds. A subsequent review by Mickevich and Parenti (1980) criticized the method Strauch used (character compatibility analysis: Estabrook 1972; Estabrook et al. 1975, 1976a,b; McMorris 1975; Estabrook et al. 1977) and discarded 35 of his 70 characters. They then analyzed the 35 characters remaining using the Wagner tree program of Farris (1978).

Mickevich and Parenti's arguments against character compatibility analysis are reasonable, but their rationale for discarding characters can in many instances be disputed. For example, nine characters were discarded for employing singlestate assignments to multistate taxa. Discarding such characters is unnecessary, since they can be made to reflect Strauch's observations simply by recoding the relevant taxa as polymorphic.

A reevaluation of Strauch's data matrix in light 


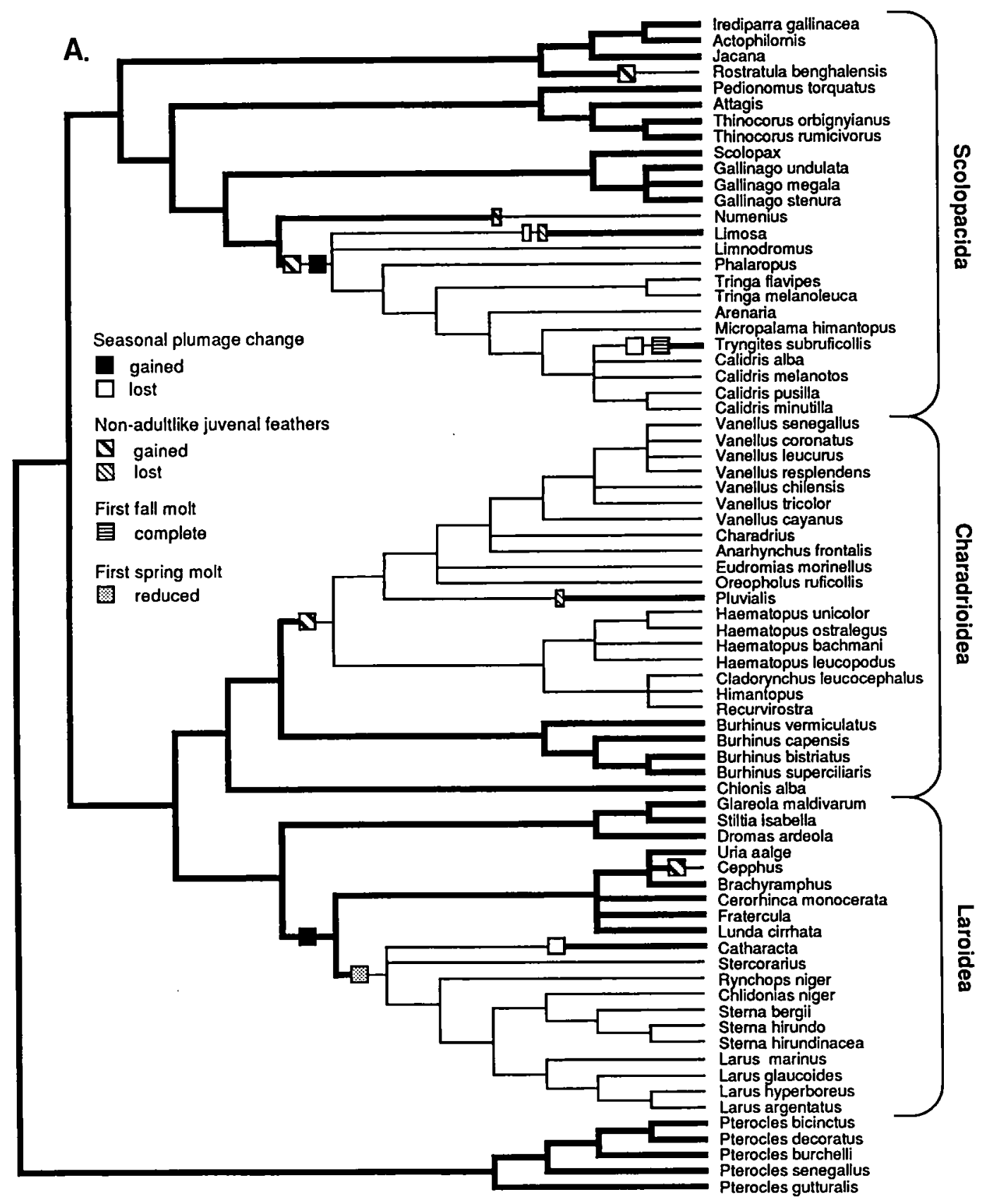

FIG. 4A. The Sibley and Ahlquist (1990) estimate of shorebird relationships. The sandgrouse (Pterocles), Sibley and Ahlquist's sister group to the shorebirds, are also shown. Names of higher taxa are taken from Sibley et al. (1988).

Modifications important in the generation or loss of delayed plumage maturation are shown on the tree, with half-width bars representing modifications that were acquired in some, but not all, members of a terminal taxon. The hierarchical level at which particular modifications were acquired appears to be unambiguous; in fact, ambiguity was often present, but in the interest of simplification it is not shown. Instead, whenever optimization indicated that a novel character state could be assigned to more than one node, it was depicted as if it had been assigned to the node closest to the branch tips.

Thin branches indicate lineages with delayed plumage maturation; thick branches, lineages without it. Note, however, that an unambiguous change in the presence or absence of delayed plumage maturation is required to change branch width from thick to thin, or vice versa. Imagine an ancestral taxon with distinctive first-year plumages, and imagine that some of the terminal taxa descended from it are of unknown condition. In such a case, the terminals would also be depicted as having distinctive first-year plumages, because there was no indication of an unambiguous change in condition between the ancestor and its descendants. Conversely, if the 
of Mickevich and Parenti's criticisms resulted in omission of only two characters, although a third character was divided into two, and the number of character states was reduced in six others (Chu MS). These coding changes rendered identical the character-state descriptions for some of the 227 taxa in the original Strauch matrix. Taxa with identical state assignments were combined under single taxon labels, reducing the number of taxa in the revised matrix to 185 .

I then added a hypothetical ancestor to the matrix (bringing the total number of taxa to 186). States were assigned to the ancestor based on Strauch's information about two outgroups, cranes and their relatives (Gruiformes) and pigeons (Columbiformes). However, state assignments were made only for those characters in which all outgroup taxa surveyed had the same character state.

The revised Strauch data matrix was analyzed cladistically using the computer program PAUP 3.0s (Phylogenetic Analysis Using Parsimony; Swofford 1991). Outgroup rooting was specified, with the hypothetical ancestor being designated as the outgroup; other details of the analysis will be published elsewhere (Chu MS). This PAUP analysis resulted in the discovery of a large number of shortest trees; I stopped the analysis after 2500 had been found. Each of the 2500 required 401 steps and had a consistency index (CI) of 0.307 (Kluge and Farris 1969; Sanderson and Donoghue 1989). It was this set of 2500 trees, and the DNA-DNA hybridization tree of Sibley and Ahlquist (1990), on which character evolution was examined.

To trace the evolution of delayed plumage maturation on the Sibley and Ahlquist tree, I used the matrix of plumage maturation characters in Appendix 2 in conjunction with PAUP's topological constraints option; topology was constrained so that only those trees consistent with the Sibley and Ahlquist phenogram were saved. Shortest trees were sought using a heuristic algorithm that employed a closest addition sequence and subtree pruning-regrafting branchswapping. I also used the MULPARS option, which saves all equally parsimonious trees and inputs them one by one into the branch-swapping procedure.

An identical procedure was used to trace the evolution of delayed plumage maturation on the shortest trees produced from the revised Strauch matrix. Because there were 2500 shortest trees, I could not examine character evolution on all of them; 6 (trees 1, 500, 1000, 1500, 2000, and 2500) were chosen for examination, each being used in turn to constrain topology. One of these (tree 1) is shown in figure 4B.

States for some of the plumage-maturation characters can be arranged into apparently sensible linear sequences. However, no hypotheses of character-state order were imposed. This practice follows Hauser and Presch (1991), who argued that hypotheses of order should be determined from a cladogram, not a priori; they stated, "the evolutionary relationships between character states, and the evolutionary processes that are compatible with those relationships, are not assumptions to be made but rather questions to be asked" (1991, p. 261).

In addition, all plumage-maturation characters were assigned a weight of zero, insuring that they would not resolve any polytomies specified in the various topological-constraints statements. This practice, in which character evolution is examined on topologies that are independent of those characters, is used to avoid circularity (e.g., Brooks and McLennan 1991); however, it is arguable (McKitrick 1993). I used it because the Sibley and Ahlquist tree was built from distance, not character, data; even if I had wished to allow the plumage maturation characters to participate in tree-building, I could not have combined them into a single analysis with Sibley and Ahlquist's distance data.

By conducting parsimony analyses on the plumage-maturation characters and simultaneously specifying topology, the simplest scheme of character evolution was estimated, both for the Sibley and Ahlquist tree and for several of the revised Strauch trees. That is, states allowing each character to evolve in the most parsimonious way were assigned to the hypothetical ancestral taxa located at each interior node. This

ancestor lacked distinctive first-year plumages, its descendants would be shown without those plumages as well. The usage of this convention explains why some taxa of unknown condition, like Jacana, are shown with delayed plumage maturation in figure $4 \mathrm{~B}$ but without it in figure $4 \mathrm{~A}$ : the most recent ancestor with unambiguous state assignments possesses distinctive first-year plumages in the former, but lacks them in the latter. 
B.

Seasonal plumage change

- gained

$\square$ lost

Non-adultlike juvenal feathers

$\mathbf{\nabla}$ gained

\$ lost

First fall molt

目 complete

First spring molt

: increased, removing age-related differences in the spring molt

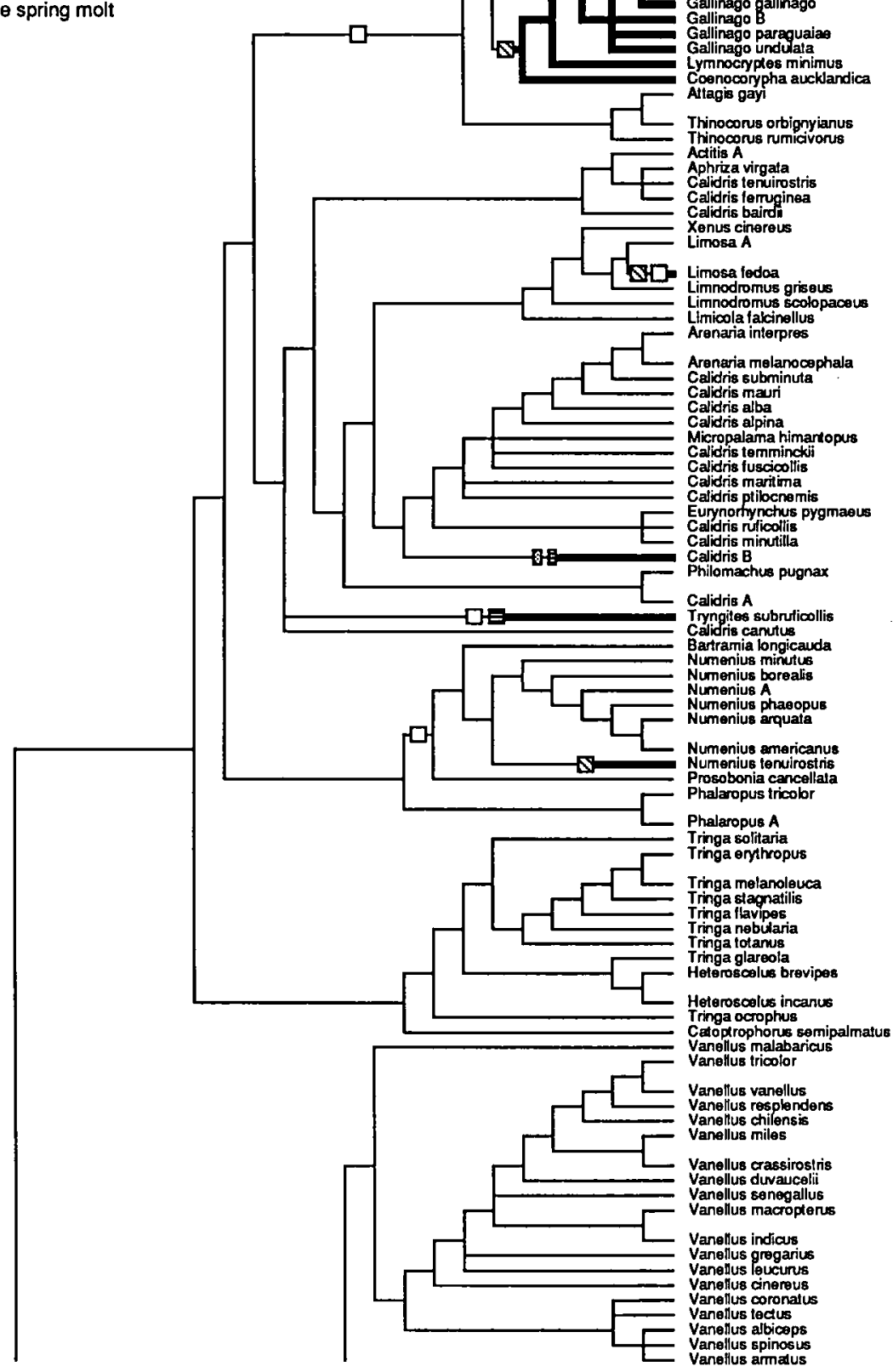

Fig. 4B. Tree 1 of the 2500 trees generated from cladistic analysis of the revised Strauch (1978) data matrix. Names of higher taxa are from Strauch (1978). 


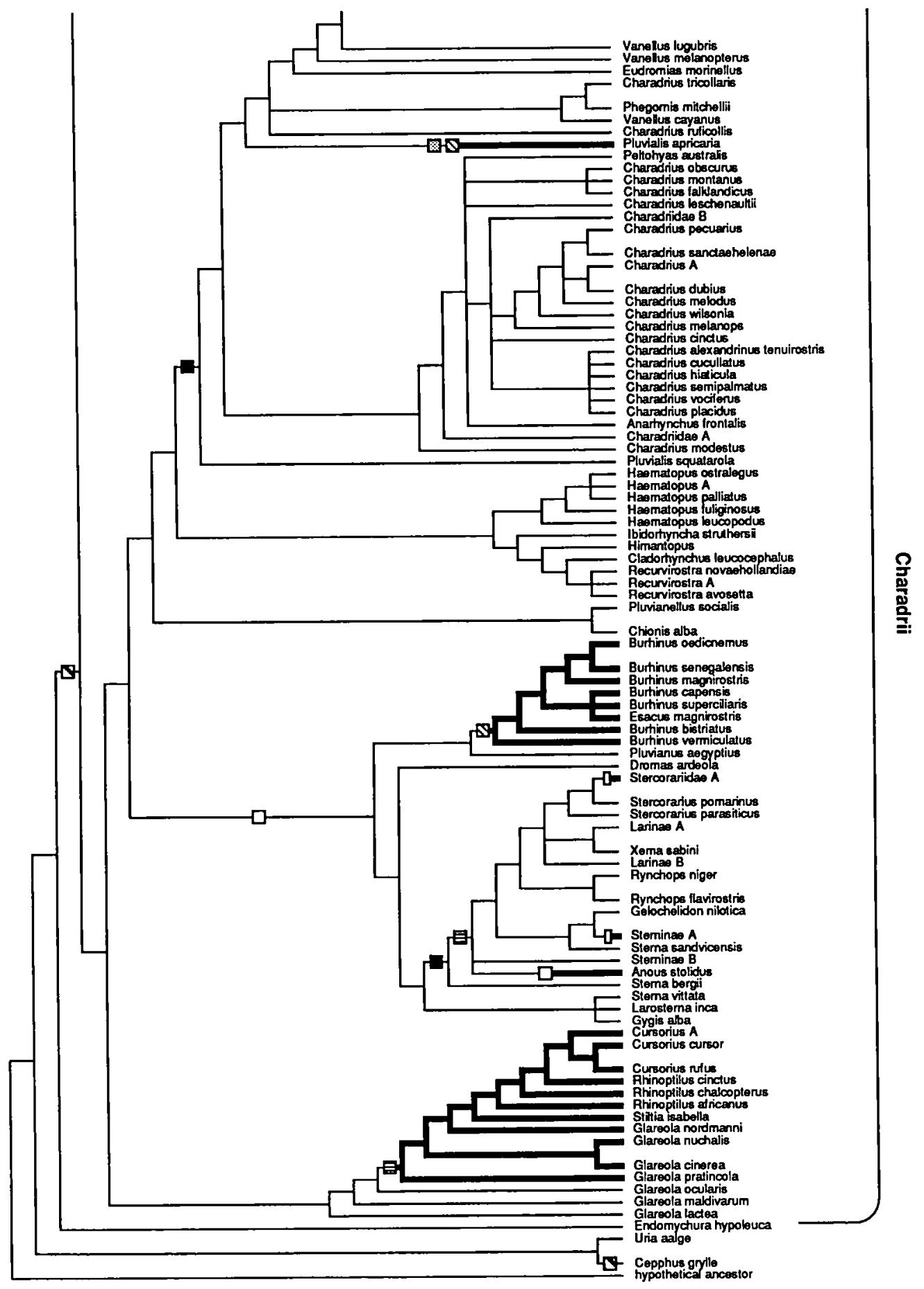

Fig. 4B. Continued.

procedure, in which parsimony is used to make state assignments to interior nodes, is called optimization (Farris 1970; Swofford and Maddison 1987).

However, there may be two or more equally parsimonious ways to optimize a character (fig. 5A,B). Where a character can be optimized two or more ways with equal simplicity, computer programs like PAUP provide several options, each of which optimizes the ambiguously dis- 
A

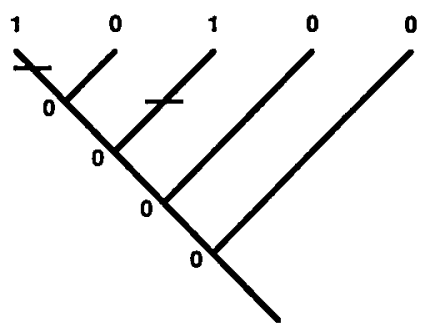

B

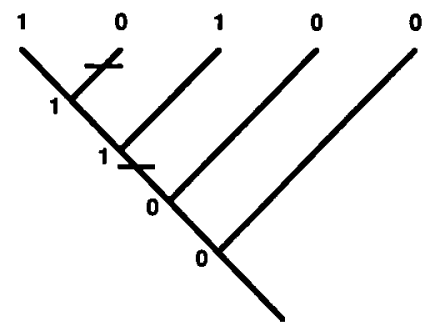

C

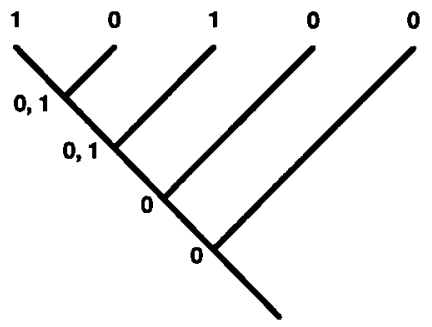

FIG. 5. Three ways to interpret an ambiguous character-state distribution. All three require a minimum of two transformations and thus are equally simple. A requires two independent gains of state $1 ; B$, a gain and subsequent loss. In $\mathrm{C}$, however, interior nodes are allowed to retain all possible state assignments; C differs from $\mathrm{A}$ and $\mathrm{B}$ in that it does not specify the exact hierarchical level at which each of the two transformations occurs.

tributed character states under a different set of assumptions. PAUP's ACCTRAN option, for example, prefers reversals to parallelisms, and thus will optimize an ambiguously distributed state so as to minimize the number of times that the state is acquired independently. Rather than use any of these options and their attendant assumptions, I allowed interior nodes to retain the multiple states assigned to them where optimization was ambiguous (fig. 5C).

Both the Sibley and Ahlquist tree and the trees generated from the revised Strauch matrix contained polytomies. As Maddison (1989) indicated, polytomies may be interpreted in two ways, as multiple speciation events or as regions of uncertain resolution. Neither is entirely satisfactory. For the uncertain-resolution interpretation, Maddison's algorithm resolves each polytomy in the way that is most favorable for the single character under consideration. This is inappropriate when, as in the present study, optimizations for several characters are to be compared. If a polytomy is to be optimized for, say, three different characters, and if, for each character, the polytomy is resolved in the way that is most favorable for that character alone, then the polytomy could be resolved in as many as three different ways (one per character; fig. 6). In other words, comparing optimizations for several characters may be equivalent to comparing optimizations on several different fully bifurcating trees (Maddison 1989). Conversely, if one believes that polytomies do not exist in nature, then comparing optimizations on fully bifurcating trees, even different ones, may be preferable to comparing them on a single polytomous trees.

PAUP 3.0s optimizes on polytomies using the multiple-speciation interpretation; a second computer program, MacClade 3.0 (Maddison and
Maddison 1992), permits either the multiplespeciation or uncertain-resolution interpretation to be used. I used the multiple-speciation interpretation primarily because it was available in PAUP, and MacClade 3.0 was not, when this study was being conducted.

\section{RESULTS}

On the Sibley and Ahlquist tree, optimization indicated 122 changes in plumage maturation characters $(\mathrm{CI}=0.303$; table 1$)$. On the revised Strauch trees that I examined, the number of changes ranged from $251(\mathrm{CI}=0.159)$ to 254 $(C I=0.157)$; the number of changes and $\mathrm{CI}$ for revised Strauch tree 1 are shown in table 1. The greater number of changes and lower consistency index shown by each of the revised Strauch trees is probably largely consequent from the greater number of taxa scored by Strauch.

\section{The Primitive Shorebird Condition}

Optimization on both the Sibley and Ahlquist topology and six of the revised Strauch topologies indicated that, in the shorebirds, the primitive first fall molt was incomplete (character 1 , state 2). Thus first winter plumage in the shorebird ancestor included both new feathers and some old ones. These are first nonbreeding and juvenal feathers, respectively.

On the revised Strauch trees examined, both first nonbreeding and juvenal feathers were hypothesized to be primitively adultlike in appearance (first nonbreeding: character 2 , state 0 ; juvenal, characters 3 through 5 , state 0 in all three cases). Consequently, first winter plumage looked like adult winter plumage, even though it was composed of feathers from two feather generations. A scenario like this one is shown in figure $2 \mathrm{~A}$. 


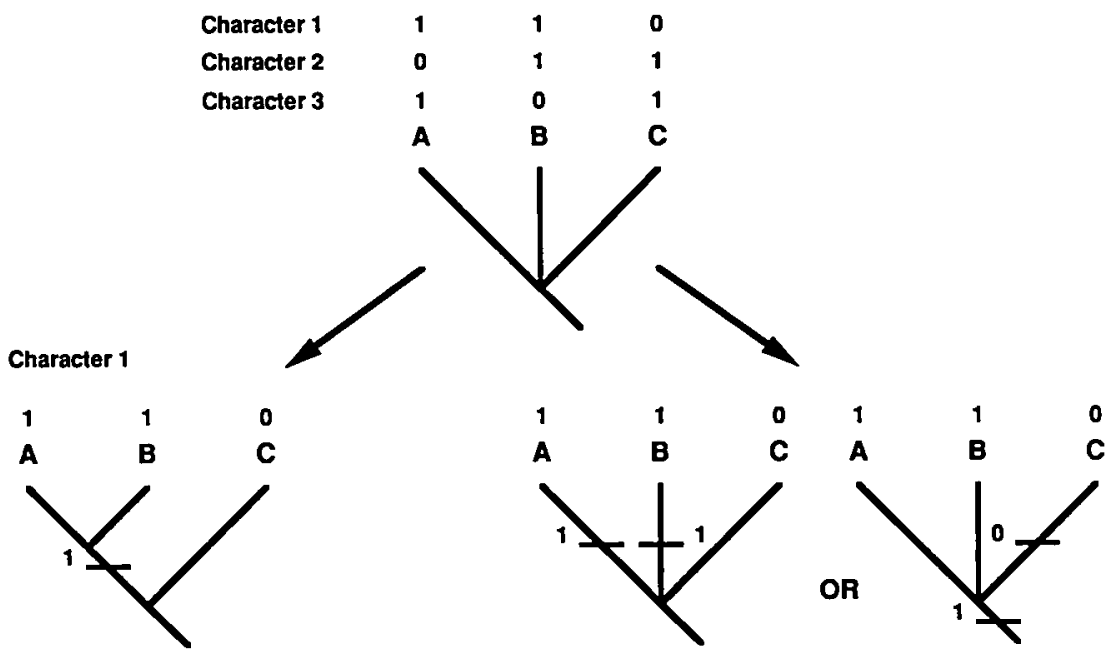

Character 2
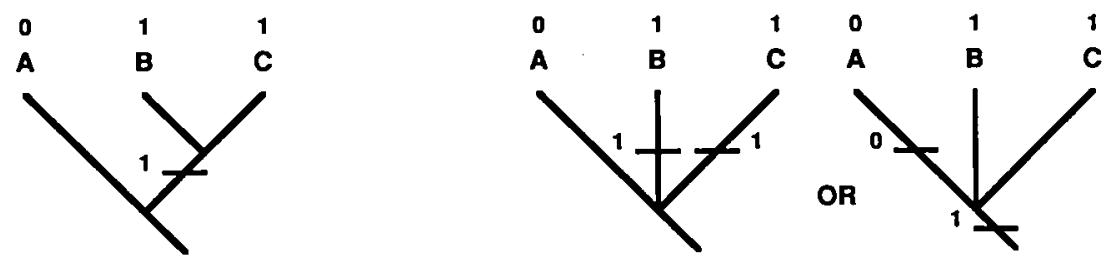

Character 3
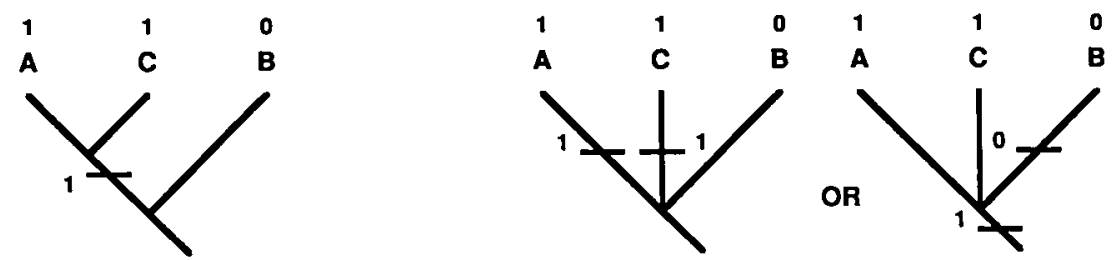

FIG. 6. Optimization on a trichotomy using both multiple-speciation and uncertain-resolution algorithms. The multiple-speciation algorithm (used in the two right-hand columns) requires two steps for each character; the uncertain-resolution algorithm (used in the left-hand column) requires only one. The difference in number of steps results because, for each character, the uncertain-resolution algorithm resolves the trichotomy in the way most favorable for that character alone. Note that the uncertain-resolution algorithm is inappropriate if the characters are to be optimized and the results of optimization compared, because characters 1-3 will each have been optimized on a different topology.

The same was true on the Sibley and Ahlquist tree, except that the state assignment for character 3 (juvenal feathers of the foreneck, breast, and flanks) was ambiguous (both states 0 and 3 were possible). However, the first fall molt assigned to the shorebird ancestor was extensive enough to replace all foreneck, breast, and flank feathers. Because all of them were replaced during the first fall, they could have no effect on first-winter appearance.
Optimization on the Sibley and Ahlquist tree also indicated that, in the ancestral shorebird condition, plumage did not vary seasonally (character 8 , state 0 ). Thus, the winter similarity between age classes was maintained into the following summer. Similar appearance was maintained despite age-related differences in the spring molt: on the Sibley and Ahlquist tree, optimization assigned the shorebird ancestor an adult spring molt that was more extensive than the 
TABLE 1. Number of modifications to, and consistency index (CI) for, each plumage maturation character. Number of modifications was determined by optimization on both the Sibley and Ahlquist (1990) topology and tree 1 of the 2500 revised Strauch (1978) topologies; the algorithm used to optimize treated polytomies as multiple speciation events. See the text for further discussion.

\begin{tabular}{lccccc}
\hline \hline & \multicolumn{2}{c}{ Sibley and Ahlquist (1990) } & & \multicolumn{2}{c}{$\begin{array}{c}\text { Revised Strauch (1978) } \\
\text { tree 1 }\end{array}$} \\
\cline { 2 - 5 } \multicolumn{1}{c}{ Character } & $\begin{array}{c}\text { No. of } \\
\text { changes }\end{array}$ & CI & & $\begin{array}{c}\text { No. of } \\
\text { changes }\end{array}$ & CI \\
\hline First fall molt & 13 & 0.385 & 25 & 0.160 \\
First nonbreeding feathers & 4 & 0.500 & 9 & 0.333 \\
Juvenal foreneck, breast, flanks & 30 & 0.233 & 68 & 0.103 \\
Juvenal belly, crissum & 15 & 0.400 & 22 & 0.273 \\
Juvenal upperpart feathers & 15 & 0.333 & 25 & 0.200 \\
First-spring molt & 14 & 0.286 & 28 & 0.214 \\
Subsequent spring molts & 9 & 0.556 & 17 & 0.353 \\
Seasonal plumage change & 14 & 0.071 & 38 & 0.026 \\
First-breeding feathers & 8 & 0.250 & 20 & 0.100 \\
ToraL & 122 & 0.303 & 252 & 0.159 \\
\hline
\end{tabular}

first spring molt (character 7 , state 3 , and character 6 , state 4 , respectively).

In contrast, optimization on five of the six revised Strauch trees that I examined (trees 1 , $1000,1500,2000$, and 2500 ) suggested that seasonal changes in plumage appearance were present, not absent, in the shorebird ancestor (character 8 , state 1 ); optimization on the sixth tree (tree 500) was ambiguous with respect to the primitive condition for seasonal change. However, even if seasonal change was shown by the shorebird ancestor, its effects on plumage maturation are unclear. Seasonal change results in distinctive first-year appearance only when combined with age-related differences in the spring molt, and the presence or absence of such differences was not resolved at the basal node in the shorebird group (first spring molt: character 6 , states 2 and 4 possible; adult spring molt: character 7 , states 1,2 , and 3 possible).

In summary, on the Sibley and Ahlquist topology, optimization indicated that the shorebird ancestor lacked delayed plumage maturation. On the revised Strauch topologies that I examined, optimization was ambiguous with respect to presence or absence of delay in the shorebird ancestor.

\section{Evolutionary Novelties Generating Delayed Plumage Maturation}

A large percentage of shorebirds show delayed plumage maturation, even though optimization indicated that the shorebird ancestor may have lacked it. On the Sibley and Ahlquist tree, where character-state reconstruction suggested a shore- bird ancestor without distinctive first-year plumages, the acquisition of such plumages can be attributed to a small number of evolutionary novelties. These are nonadultlike juvenal upperpart feathers, seasonal changes in plumage appearance, and a reduced first spring molt.

The simplest character-state reconstruction indicated that delayed plumage maturation arose four to six times on the Sibley and Ahlquist tree, once each in Sibley et al.'s (1988) plover and gull groups (the Charadrioidea and Laroidea, respectively) and two to four times in their sandpiper group (the Scolopacida). Transformations that generated delay are shown in figure $4 \mathrm{~A}$.

1. In the plover group, delayed plumage maturation arose with the acquisition of juvenal upperpart feathers that were not like those of winter adults.

2 . In the sandpiper group, nonadultlike juvenal upperpart feathers were implicated whenever delay arose.

a. They were acquired one or two times in the group (((Irediparra gallinacea, Actophilornis) Jacana)Rostratula benghalensis). Of these, only Rostratula is known to show delayed plumage maturation; first-winter and firstsummer plumages of the other three group members have not been described.

b. Nonadultlike juvenal feathers were also acquired once or twice in the Rostratula group's sister taxon, with distinctive first-year plumages appearing each time. Optimization identified two equally simple character-state reconstructions, a gain and two losses or two gains and one loss. In the latter reconstruc- 
tion, one of the gains was placed along the same interior branch as was the acquisition of seasonal plumage change, implicating both nonadultlike juvenal feathers and seasonal change in the generation of delayed plumage maturation.

3 . In the gull group, delayed plumage maturation appeared either because seasonal change was acquired or because the first spring molt was reduced, or both. Choosing between these alternatives was not possible because state assignments to both the seasonal change and spring molt characters were ambiguous at basal nodes in the Laroidea.

Nonadultlike juvenal feathers created delayed plumage maturation when they arose in a taxon retaining the primitive shorebird first fall molt. Because the primitive first fall molt was incomplete, first winter plumage was a mixture of new first nonbreeding feathers and old juvenal ones. However, before the modification of juvenalfeather appearance, the two feather types looked like their adult winter counterparts; as a consequence, first winter plumage looked like adult winter plumage (fig. 2A). After the modification of juvenal feather appearance, juvenal feathers looked different from those of winter adults, rendering first winter plumage nonadultlike (fig. 2B).

Seasonal plumage change generated delayed plumage maturation when it was acquired in a taxon having a first spring molt that was less extensive than subsequent spring molts. Under these conditions, first-year birds were unable to acquire as many breeding feathers as older birds. The difference in number of breeding feathers acquired had no effect on appearance as long as breeding feathers looked like the nonbreeding feathers they were replacing. However, once seasonal plumage variation arose, breeding and nonbreeding feathers were no longer alike, and any age-related difference in the number of breeding feathers acquired was translated into age-related differences in appearance. Compare figures $3 A$ and $3 B$. Figure $3 A$ depicts the condition before seasonal change was acquired; figure $3 \mathrm{~B}$, the condition after.

Finally, reductions in the first spring molt generated delayed plumage maturation if (as was possible in Sibley et al.'s Laroidea) they were acquired in a taxon with seasonal plumage variation. Figure $3 \mathrm{C}$ shows a bird with seasonal change in which first and subsequent spring molts were equal in extent; figure 3B shows what such a bird would look like after a reduction in the first spring molt. In the latter, first-summer birds would have fewer breeding feathers than older birds and would therefore look different from them.

Optimization on the revised Strauch trees that I examined was ambiguous with respect to delayed plumage maturation in the hypothetical ancestral shorebird. If delayed plumage maturation was lacking in the shorebird ancestor, optimization indicated that it arose at least twice (fig. 4B), once in Cepphus grylle and once in the most recent common ancestor of Strauch's (1978) plover/gull and sandpiper clades (the Charadrii and Scolopaci, respectively). In both it would have arisen when juvenal feathers acquired a nonadultlike appearance; modified juvenal feathers were those of the underparts in Cepphus and the upperparts in (Charadrii, Scolopaci).

\section{Additional Changes Arising After the Appearance of Delayed Plumage Maturation}

Optimization on the Sibley and Ahlquist and revised Strauch trees yielded reconstructions of character evolution that were generally similar. For example, on all trees examined, distinctive first-winter plumages arose when nonadultlike juvenal feathers were acquired. Subsequent changes in first-winter appearance, also indicated on all trees, resulted from the following modifications:

1. Increases and decreases in the extensiveness of the first fall molt. An increase is equivalent to a transformation from figure $2 B$ to $2 C$; a decrease, to a transformation from figure $2 \mathrm{C}$ to $2 \mathrm{~B}$.

2. The acquisition of first nonbreeding feathers that were different from their adult nonbreeding counterparts (equivalent to a change from figure $2 \mathrm{C}$ to $2 \mathrm{D}$ ).

3. Additional modifications to juvenal feathers. Modifications included changes from adultlike to nonadultlike appearance and vice versa. They also included changes from one nonadultlike character state to another.

Distinctive first-summer plumages were always generated by a combination of seasonal plumage change and age-related differences in the spring molt. On each topology examined, optimization indicated the following additional modifications affecting first-summer appearance:

1. Changes in the extensiveness of both spring molts. Either could increase or decrease; however, because of the interactive effects of the two 
molts, several different changes could have the same effect on plumage appearance. For example, age-related molt differences could be exaggerated in several ways: through an increase in the more extensive of the two spring molts; through a decrease in the less extensive one; and through simultaneous changes in both, with the more extensive one increasing more or decreasing less.

2. The acquisition of nonadultlike first breeding feathers. Whenever they were acquired they made first-summer birds look less like their adultsummer counterparts (compare figs. 3C and 3D).

3. The loss of seasonal plumage change.

Secondary losses of delayed plumage maturation were infrequent in the shorebirds, with a minimum of 4 on the Sibley and Ahlquist tree (fig. 4A) and 11 on each of the revised Strauch topologies that I examined (fig. 4B). Most of these resulted from reversals. For example, optimization on both the Sibley and Ahlquist and revised Strauch trees suggested that, in the sandpiper group, the modification of juvenal upperpart feathers played an important role in the generation of distinctive first-year plumages. Reversal of this modification helped account for one of the two losses of delayed plumage maturation in Sibley and Ahlquist's sandpiper group and three of the five losses in Strauch's sandpiper group.

The few losses of delayed plumage maturation not attributable to reversals were consequent from the acquisition of a complete first-fall molt. A complete molt during the first fall replaces all juvenal feathers before the first winter. For lineages in which modified juvenal feathers were the cause of delayed plumage maturation, the complete replacement of those feathers resulted in the loss of distinctive first-year appearance.

\section{Discussion}

Neither Sibley and Ahlquist (1990) nor Strauch (1978) scored all possible shorebirds and their relatives. For example, the former examined only 4 of about 66 gull species and subspecies, and the latter examined only 13 . The characteristics of the taxa examined determine how those taxa are grouped, and the hierarchical arrangement of groups determines the results of optimization. Thus, the taxa examined by Sibley and Ahlquist and Strauch constrain the hypotheses of character evolution presented here.

In addition, plumage-maturation character data were unavailable for a number of taxa in- cluded in both the Sibley and Ahlquist and Strauch analyses. This was particularly true with respect to the molt characters $(1,6$, and 7$)$ and the characters describing first nonbreeding and breeding feathers ( 2 and 9 ). Character for character, it was also more often true for plovers than for sandpipers or gulls. These missing data resulted in uncertain or incorrect state assignments to some interior nodes.

Nonetheless, the Sibley and Ahlquist and revised Strauch hypotheses are useful because they provide a new frame of reference for examining phenomena like delayed plumage maturation. On the Sibley and Ahlquist tree, optimization indicated a shorebird ancestor without distinctive first-year plumages; acquisition of such plumages was attributed to three evolutionary novelties: nonadultlike juvenal feathers, seasonal plumage change, and a reduction in the extent of the first spring molt. Conversely, optimization on several revised Strauch topologies was ambiguous with respect to the presence or absence of delayed plumage maturation in the shorebird ancestor; if delayed plumage maturation was lacking, character-state reconstruction suggested that it arose when nonadultlike juvenal feathers were acquired.

These modifications seem incompatible with previous hypotheses about the functions of delayed plumage maturation; minimally, they suggest alternative hypotheses that are equally plausible. For example, nonadultlike juvenal feathers generated distinctive first-year plumages when they were acquired in an ancestral taxon possessing the primitive shorebird first-fall molt, which was partial. Because the ancestral taxon retained this partial molt, it was unable to replace all of the newly modified juvenal feathers. This scenario, while supporting Rohwer and Butcher's (1988) idea that phylogenetic molt constraints played an important role in the evolution of delayed plumage maturation, does not require hypotheses of selection for distinctive first-winter or first-summer appearance. It requires only that primitive molts be retained while juvenal feathers are being modified, and the modification of juvenal feathers may be explained as a consequence of selection for some aspect of juvenile appearance, for example, cryptic coloration.

A second novel condition implicated in the generation of delayed plumage maturation was seasonal changes in plumage appearance. Seasonal change generated distinctive first-year appearance when it was acquired in an ancestral 
taxon possessing primitive, age-related differences in the spring molt, with the age-related molt differences preventing first-year birds from acquiring as many breeding feathers as older birds. In this reconstruction, selection for distinctive first-year plumages is not required to explain the evolution of delayed plumage maturation; all that is necessary is that the primitive molts be retained while seasonal plumage variation is being acquired, and the acquisition of seasonal variation can simply be viewed as a product of selection for predictable changes in appearance.

An alternative argument is that nonadultlike juvenal feathers and seasonal plumage change are two of several possible responses to selection for distinctive first-year plumages. Restricted first-year molts then become a set of fortuitous circumstances; juvenal feathers can affect firstwinter appearance only because the first-fall molt happens to be restricted, and seasonal change can affect first-summer appearance only because of limitations on the first-spring molt. However, such an argument requires that delayed plumage maturation be purchased at the price of wholesale changes to the appearance of either juveniles or summer adults. It seems simpler to assume that juvenal and breeding feathers are important to the appearance of juveniles and breeding birds, respectively, and that any affect they have on first-year individuals is an incidental consequence of retained primitive molts.

Finally, distinctive first-year plumages may in one instance have been generated by reductions in the first spring molt. For this to have occurred, age-related molt differences had to be acquired in an ancestral taxon showing seasonal plumage variation. Reduction in the first spring molt can be viewed as an additional way to create distinctive plumages for first-year birds. However, since the energetic cost of molt has been wellestablished (e.g., Dolnik 1982; King and Murphy 1985; Murphy et al. 1988), it is equally plausible to view molt reduction (and the resulting generation of delayed plumage maturation) as a secondary consequence of selection for reduced energetic demands on young birds, at a time when they are comparatively ineffective at, for example, foraging (Ashmole and Tovar 1968; MacLean 1986; Burger 1987) or avoiding adult aggression.

Optimization suggested that previous hypotheses about the functions of delayed plumage maturation may be inadequate to explain the generation of distinctive first-year plumages in the shorebirds. However, character-state reconstruction on both the Sibley and Ahlquist and revised Strauch trees does suggest that previous hypotheses are applicable to certain changes in plumagematuration characters. For example, in every case where nonadultlike first nonbreeding feathers were acquired, they exaggerated the distinctiveness of first-winter plumages. Because nonadultlike first nonbreeding feathers are hypothesized to be derived rather than primitive, and because they are grown in during the first fall molt, near the start of the first winter, they might reasonably be assumed to function in enhancing the distinctive appearance of first-winter birds.

Similarly, whenever nonadultlike first breeding feathers were acquired they increased the distinctiveness of first-summer birds. Nonadultlike appearance is hypothesized to be a derived condition for first-breeding feathers. Since firstbreeding feathers are grown in during the firstspring molt, just before the first summer, they may function to create age-related divergence in appearance during the first potential breeding season.

I have provided alternate explanations for at least some instances of delayed plumage maturation in the shorebirds. However, delayed plumage maturation has most often been studied not in shorebirds, but in sexually dichromatic passerine birds. In this regard, Rostratula benghalensis is particularly interesting because (unlike most shorebirds) it shows pronounced sexual dichromatism; adult females are patterned more boldly than adult males, and juveniles of both sexes resemble the latter.

Several scenarios can explain the evolution of delayed plumage maturation in Rostratula; all of them require a change in the appearance of one sex, a change in the appearance of juveniles, or both. However, as discussed above, modifications to juvenal plumage or to an adult plumage are most simply explained as being important to juveniles and adults, respectively. They affect first-year appearance as well, but only because they occur in an ancestral taxon retaining the primitive first-fall molt, which allows some, but not all, juvenal feathers to be replaced by adult feathers.

It is tempting to explain passerine delayed plumage maturation in similar ways. However, delayed plumage maturation is, as described here, a complicated phenomenon, determined by the interaction of a number of variable features. The order in which those features were modified was 
critical to hypothesizing how distinctive first-year plumages were acquired; estimating that order (and thus inferring the role played by each feature in the evolution of delayed plumage maturation) would not have been possible without the explicit historical framework provided by a phylogenetic hypothesis. Thus, the generality of explanations presented here awaits attempts to trace the evolution of plumage-maturation characters on phylogenies of other avian groups.

\section{ACKNOWLEDGMENTS}

G. E. Hill introduced me to delayed plumage maturation, and R. O. Prum, to approaching evolutionary questions from a phylogenetic perspective. M. C. McKitrick contributed much useful advice regarding phylogenetic analysis and character optimization. R. D. Alexander, M. J. Donoghue, R. E. Irwin, N. K. Klein, G. C. Kulesza, M. C. McKitrick, R. B. Payne, and three anonymous reviewers provided many constructive comments on earlier versions of this manuscript. G. C. Kulesza designed figure 1, and, in so doing, helped me to present the information contained in figures 2 and 3. M. C. McKitrick and R. B. Payne provided access to specimens at the University of Michigan Museum of Zoology. This study is submitted in partial fulfillment of the requirements for a Doctor of Philosophy degree at the University of Michigan.

\section{Literature Cited}

Ashmole, N. P., and S. Tovar. 1968. Prolonged parental care in Royal Terns and other birds. Auk 85: 90-100.

Britten, R. J., and D. E. Kohne. 1966. Nucleotide sequence repetition in DNA. Yearbook of the Carnegie Institution of Washington 65:78-106.

Brooks, D. R., and D. A. McLennan. 1991. Phylogeny, ecology, and behavior. University of Chicago Press, Chicago.

Brownell, E. 1983. DNA/DNA hybridization studies of muroid rodents: symmetry and rates of molecular evolution. Evolution 37:1043-1051.

Burger, A. E. 1979. Breeding biology, moult and survival of Lesser Sheathbills Chionis minor at Marion Island, sub-Antarctic region. Ardea 67:1-14.

Burger, J. 1987. Foraging efficiency in gulls: a congeneric comparison of age differences in efficiency and age of maturity. Studies in Avian Biology 10: 83-90.

Burghardt, G. M., and J. L. Gittleman. 1990. Comparative behavior and phylogenetic analysis. Pp. 192-225 in M. Bekoff and D. Jamieson, eds. Interpretation and explanation in the study of animal behavior. Westview Press, Boulder, Colo.

Coddington, J. A. 1988. Cladistic tests of adaptational hypotheses. Cladistics 4:3-22.
Cracraft, J. 1987. DNA hybridization and avian phylogenetics. Pp. 47-96 in M. K. Hecht, B. Wallace, and G. T. Prance, eds. Evolutionary biology, vol. 21. Plenum Press, New York.

Cramp, S., ed. 1985. Handbook of the birds of Europe, the Middle East, and North Africa, vol. IV. Terns to woodpeckers. Oxford University Press, Oxford.

Cramp, S., and K. E. L. Simmons, eds. 1977. Handbook of the birds of Europe, the Middle East and North Africa, vol. I. Ostrich to ducks. Oxford University Press, Oxford.

- 1983. Handbook of the birds of Europe, the Middle East and North Africa, vol. III. Waders to gulls. Oxford University Press, Oxford.

Crome, F. H. J., and D. K. Rushton. 1975. Development of plumage in the Plains-wanderer. Emu 75:181-184.

Dolnik, V. R. 1982. Population ecology of the Chaffinch (Fringilla coelebs). Proceedings of the Zoological Institute of the Academy of Sciences of the USSR. 90:1-301.

Donoghue, M. J. 1989. Phylogenies and the analysis of evolutionary sequences, with examples from seed plants. Evolution 43:1137-1156.

Estabrook, G. F. 1972. Cladistic methodology: a discussion of the theoretical basis for the induction of evolutionary history. Annual Review of Ecology and Systematics 3:427-456.

Estabrook, G. F., C. S. Johnson, Jr., and F. R. McMorris. 1975. An idealized concept of the true cladistic character. Mathematical Biosciences 23: 263-272.

- 1976a. A mathematical foundation for the analysis of cladistic character compatibility. Mathematical Biosciences 29:181-187.

- 1976b. An algebraic analysis of cladistic characters. Discrete Mathematics 16:141-147.

Estabrook, G. F., J. G. Strauch, Jr., and K. L. Fiala. 1977. An application of compatibility analysis to the Blackiths' data on orthopteroid insects. Systematic Zoology 26:269-276.

Farris, J. S. 1970. Methods for computing Wagner trees. Systematic Zoology 19:83-92.

. 1978. WAGNER 78. State University of New York, Stony Brook, N.Y.

Felsenstein, J. 1985. Phylogenies and the comparative method. American Naturalist 125:1-15.

Ficken, M. S., and R. W. Ficken. 1967. Age-specific differences in the breeding behavior and ecology of the American Redstart. Wilson Bulletin 79:188189.

Foster, M. S. 1987. Delayed maturation, neoteny, and social system differences in two manakins of the genus Chiroxiphia. Evolution 41:547-558.

Gohringer, R. 1951. Vergleichende Untersuchungen uber das Juvenil-und Adultkleid bei der Amsel (Turdus merula L.) und beim Star (Sturnus vulgaris L.). Revue suisse de Zoologie 58:279-358.

Harrison, P. 1983. Seabirds: an identification guide. Croom Helm, London.

Hauser, D. L., and W. Presch. 1991. The effect of ordered characters on phylogenetic reconstruction. Cladistics 7:243-265.

Hayman, P., J. Marchant, and T. Prater. 1986. Shore- 
birds: an identification guide to the waders of the world. Croom Helm, London.

Houde, P. 1987. Critical evaluation of DNA hybridization studies in avian systematics. Auk 104:1732.

Humphrey, P. S., and K. C. Parkes. 1959. An approach to the study of molts and plumages. Auk 76:1-31.

Jehl, J. R., Jr. 1975. Pluvianellus socialis: biology, ecology, and relationships of an enigmatic Patagonian shorebird. Transactions of the San Diego Society of Natural History 18:25-74.

King, J. R., and M. E. Murphy. 1985. Periods of nutritional stress in the annual cycles of endotherms: fact or fiction? American Zoologist 25:955964.

Kluge, A. G., and J. S. Farris. 1969. Quantitative phyletics and the evolution of anurans. Systematic Zoology 18:1-32.

Lack, D. L. 1954. The natural regulation of animal numbers. Clarendon Press, Oxford.

- 1968. Ecological adaptations for breeding in birds. Methuen, London.

Lanyon, S. M. 1992. Review of, "Phylogeny and classification of birds. A study in molecular evolution." Condor 94:304-307.

Lauder, G. V. 1989. Caudal fin locomotion in rayfinned fishes: historical and functional analyses. American Zoologist 29:85-102.

Lyon, B. E., and R. D. Montgomerie. 1986. Delayed plumage maturation in passerine birds: reliable signaling by subordinate males? Evolution 40:605615.

MacLean, A. A. E. 1986. Age-specific foraging ability and the evolution of deferred breeding in three species of gulls. Wilson Bulletin 98:267-279.

Maddison, W. 1989. Reconstructing character evolution on polytomous cladograms. Cladistics 5:365377.

Maddison, W. P., and D. P. Maddison. 1992. MacClade, version 3. Sinauer, Sunderland, Mass.

McKitrick, M. C. 1992. Phylogenetic analysis of avian parental care. Auk 109:828-846.

-1993. Trends in the evolution of hindlimb musculature in aerial-foraging birds. Auk 110:189206.

McMorris, F. R. 1975. Compatibility criteria for cladistic and qualitative taxonomic characters. Pp. 399415 in G. F. Estabrook, ed. Proceedings of the Eighth International Conference on Numerical Taxonomy. W. H. Freeman, San Francisco.

Mickevich, M. F., and L. R. Parenti. 1980. Review of, "The phylogeny of the Charadriiformes (Aves): a new estimate using the method of character compatibility analysis." Systematic Zoology 29:108-113.

Murphy, M. E., J. R. King, and J. Lu. 1988. Malnutrition during the postnuptial molt of Whitecrowned Sparrows: feather growth and quality. $\mathrm{Ca}$ nadian Joumal of Zoology 66:1403-1413.

O'Hara, R. J. 1988. Homage to Clio, or, toward an historical philosophy for evolutionary biology. Systematic Zoology 37:142-155.

Pagel, M. D., and P. H. Harvey. 1988. Recent developments in the analysis of comparative data. Quarterly Review of Biology 63:413-440.
Payne, R. B. 1972. Mechanisms and control of molt. Pp. 103-155 in D. S. Farner and J. R. King, eds. Avian biology, vol. 2. Academic Press, New York.

Procter-Gray, E., and R. T. Holmes. 1981. Adaptive significance of delayed attainment of plumage in male American Redstarts: tests of two hypotheses. Evolution 35:742-751.

Ridley, M. 1983. The explanation of organic diversity: the comparative method and adaptations for mating. Clarendon, Oxford.

Rohwer, S., and G. S. Butcher. 1988. Winter versus summer explanations of delayed plumage maturation in temperate passerine birds. American Naturalist 131:556-572.

Rohwer, S., S. D. Fretwell, and D. M. Niles. 1980. Delayed maturation in passerine plumages and the deceptive acquisition of resources. American Naturalist 115:400-437.

Rohwer, S., W. P. Klein, and S. Heard. 1983. Delayed plumage maturation and the presumed prealternate molt in American Redstarts. Wilson Bulletin 95: 199-208.

Sanderson, M. J., and M. J. Donoghue. 1989. Patterns of variation in levels of homoplasy. Evolution 43:1781-1795.

Sarich, V. M., C. W. Schmid, and J. Marks. 1989. DNA hybridization as a guide to phylogenies: a critical analysis. Cladistics 5:3-32.

Schildkraut, C., J. Marmur, and P. Doty. 1961. The formation of hybrid DNA molecules and their use in studies of DNA homologies. Journal of Molecular Biology 5:595-617.

Selander, R. K. 1965 . On mating systems and sexual selection. American Naturalist 49:129-141.

Sheldon, F. H. 1987. Phylogeny of herons estimated from DNA-DNA hybridization data. Auk 104:97108.

Shields, G. F., and N. A. Straus. 1975. DNA-DNA hybridization studies of birds. Evolution 29:159166.

Sibley, C. G., and J. E. Ahlquist. 1981. The phylogeny and relationships of ratite birds as indicated by DNA-DNA hybridization. Pp. 301-335 in G. G. E. Scudder and J. L. Reveal, eds. Evolution today, Proceedings of the Second International Congress of Systematic and Evolutionary Biology. University of British Columbia, Vancouver.

- 1984. The phylogeny of the hominoid primates, as indicated by DNA-DNA hybridization. Journal of Molecular Evolution 20:2-15.

_. 1990. Phylogeny and classification of birds. A study in molecular evolution. Yale University Press, New Haven, Conn.

Sibley, C. G., J. E. Ahlquist, and B. L. Monroe, Jr. 1988. A classification of the living birds of the world based on DNA-DNA hybridization studies. Auk 105:409-423.

Sillén-Tullberg, B. 1988 . Evolution of gregariousness in aposematic butterfly larvae: a phylogenetic analysis. Evolution 42:293-305.

Springer, M., and C. Krajewski. 1989. DNA hybridization in animal taxonomy: a critique from first principles. Quarterly Review of Biology 64:291318.

Strauch, J. G., Jr. 1978. The phylogeny of the Charad- 
riiformes (Aves): a new estimate using the method of character compatibility analysis. Transactions of the Zoological Society of London 34:263-345.

Studd, M. V., and R. J. Robertson. 1985. Life span, competition, and delayed plumage maturation in male passerines: the breeding threshold hypothesis. American Naturalist 126:101-115.

Swofford, D. L. 1991. PAUP: Phylogenetic Analysis Using Parsimony, Version 3.0s. Illinois Natural History Survey, Champaign, Ill.

Swofford, D. L., and W. P. Maddison. 1987. Reconstructing ancestral character states under Wagner parsimony. Mathematical Biosciences 87:199-229.

Urban, E. K., C. H. Fry, and S. Keith, eds. 1986. The birds of Africa, vol. II. Academic Press, London.

Wiley, R. H. 1974. Evolution of social organization and life-history pattems among grouse. Quarterly Review of Biology 49:201-227.

Wittenberger, J. F. 1979. A model for delayed reproduction in iteroparous animals. American Naturalist 114:439-446.

Corresponding Editor: M. J. Donoghue

\section{APPENDIX}

\section{States for Plumage-Maturation Characters}

Plumage-maturation characters are listed below. For each character the character states are described and numbered; the numbers function solely to identify states, and imply neither polarity decisions nor the ordering of states into a transformation series.

1. Extensiveness of the first fall molt.

0 , absent.

1, head, neck, and body.

2 , head, neck, body, some upper secondary coverts, and sometimes the central tail feathers.

3 , complete in some individuals and incomplete in others. Individuals with the most restricted first-fall molt exchange head, neck, body, and some upper secondary coverts.

4 , complete.

5 , head, neck, body, some upper secondary coverts, some tail feathers, some primaries, and some secondaries.

\section{Appearance of the first nonbreeding feathers.}

0 , like their adult nonbreeding counterparts.

1, like their juvenal counterparts.

2, like their adult nonbreeding counterparts except on the belly, axillaries, and underwing coverts. In these regions they look like their juvenal counterparts.

3 , intermediate in appearance between their juvenal and adult nonbreeding counterparts.

3. Appearance of the juvenal feathers of the foreneck, breast, and flanks.

0 , like their adult nonbreeding counterparts.

1 , similar to their adult nonbreeding counterparts, but white areas with a buffy wash.

2 , white with a buffy or yellowish wash where their adult nonbreeding counterparts are dark.

3, like their adult nonbreeding female counterparts.

4, similar to their adult nonbreeding counterparts, but more strongly patterned.
5, similar to their adult nonbreeding counterparts, but duller.

6, dusky where their adult nonbreeding counterparts are white.

7, white where their adult nonbreeding counterparts have color.

4. Appearance of the juvenal feathers of the belly and under-tail coverts.

0 , like their adult nonbreeding counterparts.

1, marked with irregular dark barring, mottling, and/ or clouding, unlike their adult nonbreeding counterparts (which are unpigmented in these regions). Relatively pale individuals have an unmarked lower belly; individuals that are paler still are unmarked on the lower belly, crissum, and distal flanks.

2, white where their adult nonbreeding counterparts have color.

3, unlike their adult nonbreeding counterparts on the belly, where they are barred and checkered rather than uniformly colored.

4, like their adult nonbreeding female counterparts.

5 , similar to their adult nonbreeding counterparts, but with gray areas brownish.

6, similar to their adult nonbreeding counterparts, but duller.

7, showing a wash of color where their adult nonbreeding counterparts are white.

\section{Appearance of the juvenal upperpart feathers.}

0 , like their adult nonbreeding counterparts.

1 , feathers basally pale, subterminally dark, and bordered by pale edges or pale notching. The subterminal dark area may be narrow, in which case the feather center is colored similarly to its adult nonbreeding counterpart. Conversely, the dark area may be expanded to occupy most of the feather center. Larger dark-centered feathers (such as the tertials and long scapulars) often have pale internal markings.

2, like their adult nonbreeding male counterparts. Adult nonbreeding females have darker feathers that tend to lack pale borders and internal markings.

3, similar to their adult nonbreeding counterparts, but with black areas grayish and paler.

4, more finely patterned than their adult nonbreeding counterparts.

5 , duller than their adult nonbreeding counterparts, with a greenish sheen and pale feather edges.

6. Extensiveness of the first spring molt.

0 , absent.

1, at its maximum extent, head and neck; reduced or absent in some individuals.

2 , head, neck, and body.

3 , head, neck, body, often some upper secondary coverts, and often central tail feathers.

4, at its maximum extent, head, neck, body, some upper secondary coverts, and central tail feathers; reduced or absent in some individuals.

5 , at its maximum extent, head, neck, and body. Reduced or absent in some individuals.

6, complete, except for the primaries and secondaries. 7 , complete.

7. Extensiveness of subsequent spring molts.

0 , absent. 
1, head and neck.

2 , head, neck, and body.

3 , head, neck, body, often some upper secondary coverts, and often central tail feathers.

4, at its maximum extent, head, neck, body, some upper secondary coverts, and central tail feathers; reduced or absent in some individuals.

5 , head, neck, tail, inner primaries, body, and often some upper secondary coverts.

6, complete, except for primaries and secondaries.

8. Seasonal changes in plumage appearance.

0 , absent.

1 , present.
9. Appearance of the first breeding feathers.

0 , like their first-winter counterparts.

1 , intermediate in appearance between their first-winter and adult-summer counterparts.

2, like their adult-summer counterparts.

(I assigned taxa a "?" for character 9 if there is no firstspring molt, i.e., if no first-breeding feathers are molted in. I also assigned a "?" if extent of the first spring molt is unknown, or if plumage does not vary seasonally. Scoring taxa without seasonal plumage change as a "?" was necessary because, in the absence of seasonal variation, first-winter and adult-summer plumages can be identical; i.e., state 0 can be equivalent to state 2.) 


\section{APPENDIX 2}

\section{Sibley and Ahlquist Data Matrix}

Shown below are plumage-maturation character states for the shorebird taxa included in Sibley and Ahlquist (1990). The Sibley and Ahlquist topology was specified using the topological constraints option available in PAUP 3.0s (Swofford 1991). Each plumage-maturation character was assigned a weight of zero; had the characters not been given zero weight, they would have resolved certain polytomies present in the Sibley and Ahlquist tree. Notice that many terminal taxa exhibited multiple states for various plumage-maturation characters. Multiple-state assignments were sometimes a consequence of individual variation. Often, however, they resulted from Sibley and Ahlquist's use of genera as terminal taxa. For example, one terminal taxon is the genus Limosa; however, Limosa includes four species, L. limosa, L. haemastica, L. lapponica, and $L$. fedoa. Because Sibley and Ahlquist do not identify which of the four were used, I was forced to assume that they had used all four. The result was a polymorphic terminal taxon that had multiple states for characters $3,5,8$, and 9 . Multiple states are encoded as follows: $a=0,1 ; b=0,2 ; c=0,3 ; d=0,4 ; e=0,6 ; f=0,7 ; g=0,1,2 ; h=0,1,4$; $\mathrm{i}=0,2,7 ; \mathrm{j}=1,2 ; \mathrm{k}=2,3 ; \mathrm{m}=1,3 ; \mathrm{n}=3,4 ; \mathrm{o}=4,5 ; \mathrm{p}=3,5 ; \mathrm{q}=1,2,3 ; \mathrm{r}=2,3,4 ; \mathrm{s}=3,4,5 ; \mathrm{t}=1$, $2,3,4$; and $u=0,1,4,5,6$. I directed PAUP to interpret multistate taxa as polymorphic. Other details of the analysis are described in the Materials and Methods section.

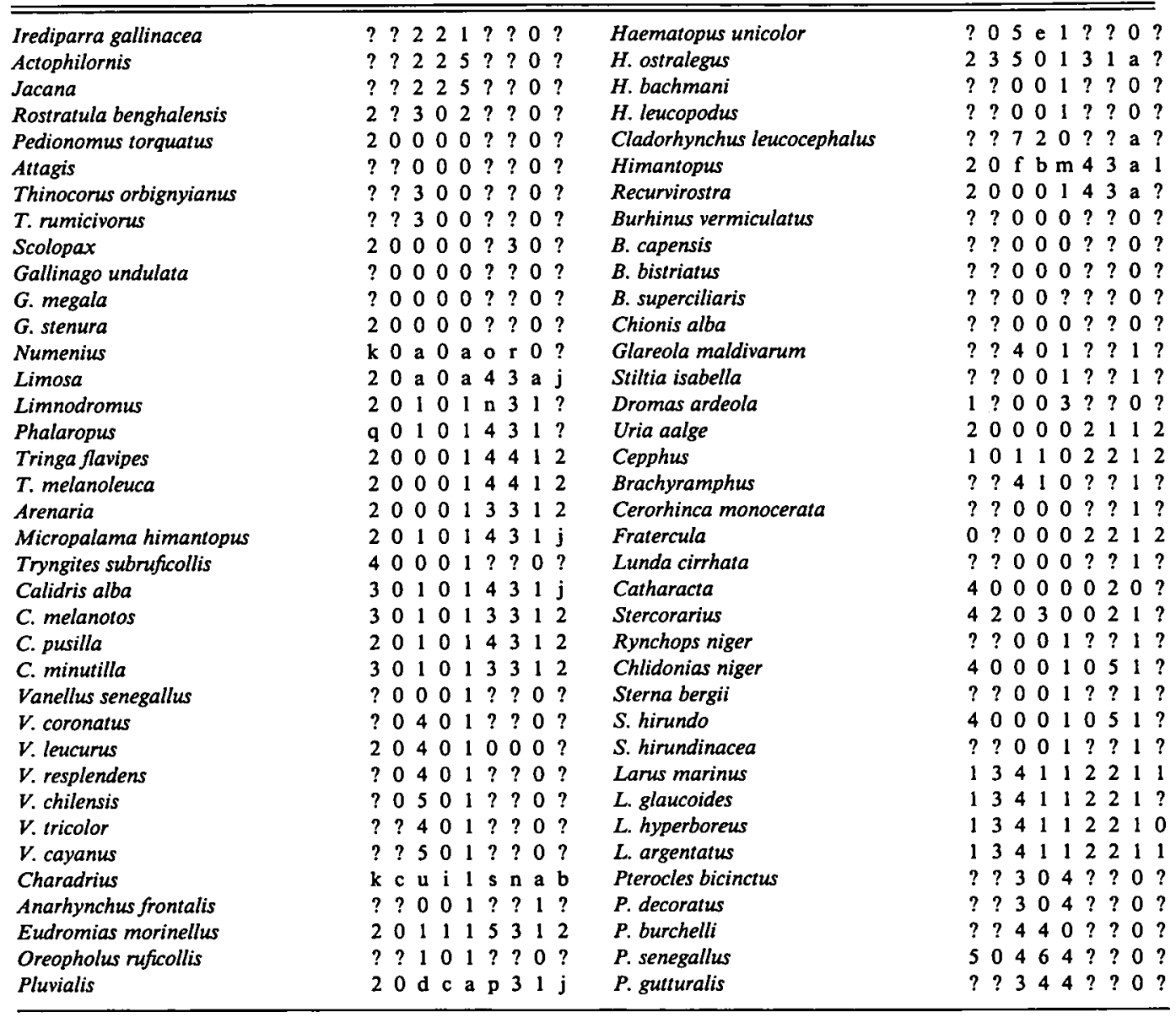




\section{APPENDIX 3}

\section{Strauch Data Matrix}

Character-state data for the taxa examined by Strauch (1978) are presented below. The plumage-maturation characters had the potential to add a degree of resolution to some of the polytomies in the revised Strauch trees. To counteract the possibility of additional resolution, that is, to retain exactly the revised Strauch topologies, I assigned each plumage-maturation character a weight of zero. Many taxa had multiple states for one or another of the plumage-maturation characters. As in Appendix 2, multiple-state assignments were sometimes a product of individual variation. However, they frequently also resulted from the use of species groups as terminal taxa. As described in the text, revision of the Strauch data matrix, with its attendant recoding of characters, rendered some of Strauch's terminal taxa identical; taxa with identical character-state descriptions were then combined under a single taxon label. This simplified PAUP analysis of the revised Strauch matrix, but the presence of taxa comprising several species sometimes resulted in the assignment of multiple states to those taxa. Multiple states are encoded as follows: $a=0,1 ; b=0,2 ; c=0,3 ; d=0,4 ; e=0,5 ; f=0,6 ; g=0,1,2 ; h=0,1,3$; $\mathrm{i}=0,1,5 ; \mathrm{j}=0,4,5 ; \mathrm{k}=1,2 ; \mathrm{m}=1,4 ; \mathrm{n}=1,5 ; \mathrm{o}=1,6 ; \mathrm{p}=2,3 ; \mathrm{q}=2,4 ; \mathrm{r}=2,6 ; \mathrm{s}=3,4 ;$ and $\mathrm{t}=4$, 5. PAUP 3.0s (Swofford 1991) was directed to interpret multiple-state taxa as polymorphic. Further details of the analysis are discussed in the Materials and Methods section. As indicated above, the terminal taxa in the revised Strauch matrix include some groups of species, subsumed under single taxon labels. Taxon labels, followed by the species they include, are: Jacanidae A (Actophilornis africana, Irediparra gallinacea); Gallinago A (G. megala, G. nigripennis); Gallinago B ( $G$. macrodactyla, G. media); Numenius A ( $N$. tahitiensis, N. madagascariensis); Limosa A (L. limosa, L. haemastica, L. lapponica); Phalaropus A (P. lobatus, P. fulicarius); Actitis A (A. macularia, A. hypoleucos); Calidris A (C. melanotos, C. acuminata); Calidris B (C. pusilla, C. minuta); Charadriidae A (Charadrius mongolus, C. bicinctus, C. asiaticus, Pluvialis dominica); Charadriidae B (Charadrius collaris, $C$. venustus, $C$. ruficapillus, $C$. alticola, $C$. veredus, Thinornis novaeseelandiae); Charadrius A ( $C$. marginatus, $C$. alexandrinus dealbatus); Haematopus A ( $H$. finschi, $H$. moquini, $H$. frazari, $H$. bachmani, $H$. ater); Recurvirostra A ( $R$. americana, $R$. andina); Cursorius A (C. coromandelicus, C. temminckii); Stercorariidae A (Catharacta skua, Stercorarius longicaudus); Sterninae A (Sterna hirundo, Anous minutus); Sterninae B (Chlidonias niger, Phaetusa simplex, Hydroprogne caspia, Sterna trudeaui); Larinae A (Larus scoresbii, Pagophila eburnea, Larus philadelphia, L. minutus, Rhodostethia rosea, Rissa tridactyla); and Larinae B (Larus heermanni, L. delawarensis, L. argentatus, L. serranus, L. novaehollandiae, Creagrus furcatus).

\begin{tabular}{|c|c|c|c|c|c|c|c|c|c|c|c|c|c|}
\hline Metopidius indicus & $? ?$ & 22 & $1 ?$ & & 0 & $?$ & Xenus cinereus & 20 & 40 & & & 31 & $1 \mathrm{k}$ \\
\hline Microparra capensis & $? ?$ & 00 & $? ?$ & & 0 & $?$ & Limosa A & 20 & 10 & & 4 & 31 & $1 \mathrm{k}$ \\
\hline Jacanidae A & ?? & 22 & $\mathrm{n}$ ? & & 0 & $?$ & L. fedoa & $? 00$ & 00 & 0 & $?$ & & 0 ? \\
\hline Actophilornis albinucha & $? ?$ & 22 & $?$ ? & ? ? & 0 & $?$ & Limnodromus griseus & 20 & 10 & & 4 & 3 & $1 ?$ \\
\hline Hydrophasianus chirurgus & $? ?$ & 10 & $1 ?$ & ? ? & 1 & $?$ & L. scolopaceus & 20 & 10 & & 3 & 3 & 1 ? \\
\hline Jacana jacana & $? ?$ & 22 & $5 ?$ & & 0 & $?$ & Phalaropus tricolor & 30 & 10 & 1 & 4 & & 1 ? \\
\hline$J$. spinosa & ? ? & 22 & $5 ?$ & ? ? & 0 & $?$ & Phalaropus A & k 0 & 10 & 1 & $?$ & & $1 ?$ \\
\hline Rostratula benghalensis & $2 ?$ & 30 & $2 ?$ & ? ? & 0 & $?$ & Tringa solitaria & 30 & 40 & & 3 & 3 & 12 \\
\hline Nycticryphes semicollaris & $? ?$ & 10 & $1 ?$ & ? ? & 0 & $?$ & T. glareola & 20 & 40 & 1 & 4 & 3 & $1 \mathrm{k}$ \\
\hline Attagis gayi & $? ?$ & 00 & $0 ?$ & $? ?$ & 0 & $?$ & T. erythropus & 20 & 43 & & 4 & 3 & $1 \mathrm{k}$ \\
\hline Thinocorus orbignyianus & $? ?$ & 30 & 0 ? & ? ? & 0 & $?$ & T. totanus & 20 & 00 & 1 & 4 & 3 & 12 \\
\hline T. rumicivorus & $? ?$ & 30 & $0 ?$ & ? ? & 0 & $?$ & T. flavipes & 20 & 00 & 1 & 4 & 4 & 12 \\
\hline Scolopax mira & $? ?$ & ? ? & ? ? & ? ? & 0 & $?$ & T. melanoleuca & 200 & 00 & 1 & 4 & 4 & 12 \\
\hline S. rusticola & 20 & 00 & $0 ?$ & $? 3$ & 30 & $?$ & T. ocrophus & 200 & 00 & 1 & 2 & 3 & 12 \\
\hline Philohela minor & $? ?$ & 00 & $0 ?$ & $? ?$ & 0 & $?$ & T. nebularia & 20 & 00 & 1 & 4 & 3 & 12 \\
\hline Gallinago hardwickii & $? 0$ & 00 & $1 ?$ & $?$ ? & 0 & $?$ & T. stagnatilis & 20 & 00 & $i$ & 4 & 3 & 12 \\
\hline G. stenura & 20 & 00 & $0 ?$ & ? ? & ? 0 & $?$ & Catoptrophorus semipalmatus & $? 0$ & 00 & 1 & $?$ & $?$ & $1 ?$ \\
\hline Gallinago A & $? 0$ & 00 & $0 ?$ & $?$ ? & ? 0 & $?$ & Heteroscelus brevipes & $? ?$ & 40 & 1 & $?$ & $?$ & $1 ?$ \\
\hline Gallinago B & 20 & 00 & d? & ? 3 & 30 & $?$ & H. incanus & $? ?$ & 40 & 1 & $?$ & $?$ & $1 ?$ \\
\hline G. gallinago & 20 & 00 & 0 & 33 & 30 & $?$ & Prosobonia cancellata & $? ?$ & 00 & 0 & $?$ & $?$ & 0 ? \\
\hline G. paraguaiae & $? 0$ & 00 & 0 & $?$ ? & $? 0$ & $?$ & Arenaria interpres & 20 & 00 & 1 & 3 & 3 & 12 \\
\hline G. undulata & $? 0$ & 00 & 0 & ? ? & ? 0 & $?$ & A. melanocephala & $? 00$ & 00 & 1 & $?$ & $?$ & $1 ?$ \\
\hline Lymnocryptes minimus & $? 0$ & 00 & 0 & $? ?$ & ? 0 & $?$ & Eurynorhynchus pygmaeus & $? 0$ & 10 & 1 & $?$ & $?$ & $1 ?$ \\
\hline Coenocorypha aucklandica & $? 0$ & 00 & 0 & ? ? & ? 0 & $?$ & Limicola falcinellus & 20 & 10 & & 4 & 3 & 12 \\
\hline Bartramia longicauda & $2 \mathrm{c}$ & 00 & 1 & ? ? & ? 0 & $?$ & Micropalama himantopus & 20 & 10 & & 4 & 31 & $1 \mathrm{k}$ \\
\hline Numenius minutus & 30 & 10 & 1 & & 20 & $?$ & Tryngiles subruficollis & 400 & 00 & $i$ & $?$ & & 0 ? \\
\hline$N$. borealis & $? ?$ & 00 & 0 & $?$ ? & $? 0$ & $?$ & Philomachus pugnax & 20 & 10 & 1 & 4 & 31 & 12 \\
\hline N. tenuirostris & 20 & 00 & 0 & 43 & 30 & $?$ & Calidris tenuirostris & 20 & 10 & 1 & 5 & 3 & 11 \\
\hline Numenius A & $? ?$ & a 0 & a & ? ? & ? 0 & $?$ & C. canutus & 20 & 10 & 1 & 4 & 31 & 11 \\
\hline N. phaeopus & 20 & 10 & 1 & ? ? & ? 0 & $?$ & C. alba & 30 & 10 & 1 & 4 & 3 & $1 \mathrm{k}$ \\
\hline N. arquata & 20 & 10 & 1 & 44 & 40 & $?$ & Calidris B & q 0 & 10 & & $\mathbf{s}$ & 31 & 12 \\
\hline N. americanus & $? ?$ & 00 & 0 & $?$ ? & $? 0$ & $?$ & C. mauri & 20 & 10 & & 4 & 3 & $1 ?$ \\
\hline Actitis & 40 & 00 & 1 & 43 & & $\mathbf{k}$ & C. ruficollis & 10 & 10 & 1 & 6 & 6 & 12 \\
\hline Aphriza virgata & ? 0 & 40 & 1 & $?$ ? & ? 1 & $?$ & C. temminckii & 50 & 10 & 1 & 3 & 3 & 12 \\
\hline
\end{tabular}


ApPENDIX 3. Continued.

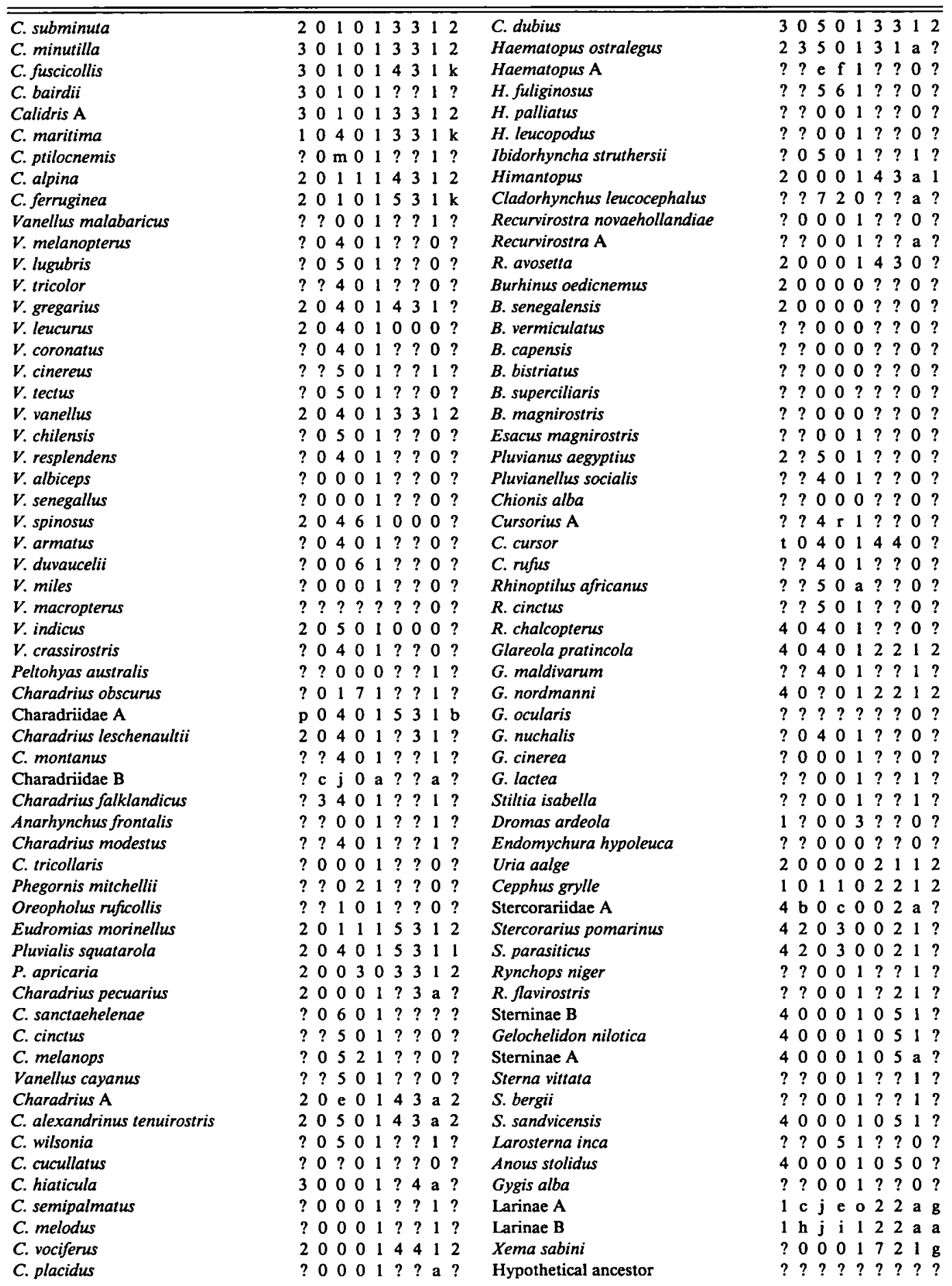

